\title{
Acid Sphingomyelinase, a Lysosomal and Secretory Phospholipase C, Is Key for Cellular Phospholipid Catabolism
}

\author{
Bernadette Breiden ${ }^{1}($ D and Konrad Sandhoff $2, *$ (D) \\ 1 Independent Researcher, 50181 Bedburg, Germany; bbreiden@gmx.de \\ 2 Membrane Biology and Lipid Biochemistry Unit, LIMES Institute, University of Bonn, 53121 Bonn, Germany \\ * Correspondence: sandhoff@uni-bonn.de; Tel.: +49-228-73-5346
}

Citation: Breiden, B.; Sandhoff, K. Acid Sphingomyelinase, a Lysosomal and Secretory Phospholipase C, Is Key for Cellular Phospholipid Catabolism. Int. J. Mol. Sci. 2021, 22, 9001. https://doi.org/10.3390/ ijms22169001

Academic Editor: Grzegorz Wegrzyn

Received: 12 July 2021

Accepted: 16 August 2021

Published: 20 August 2021

Publisher's Note: MDPI stays neutral with regard to jurisdictional claims in published maps and institutional affiliations.

Copyright: (C) 2021 by the authors Licensee MDPI, Basel, Switzerland. This article is an open access article distributed under the terms and conditions of the Creative Commons Attribution (CC BY) license (https:/ / creativecommons.org/licenses/by/ $4.0 /)$.

\begin{abstract}
Here, we present the main features of human acid sphingomyelinase (ASM), its biosynthesis, processing and intracellular trafficking, its structure, its broad substrate specificity, and the proposed mode of action at the surface of the phospholipid substrate carrying intraendolysosomal luminal vesicles. In addition, we discuss the complex regulation of its phospholipid cleaving activity by membrane lipids and lipid-binding proteins. The majority of the literature implies that ASM hydrolyses solely sphingomyelin to generate ceramide and ignores its ability to degrade further substrates. Indeed, more than twenty different phospholipids are cleaved by ASM in vitro, including some minor but functionally important phospholipids such as the growth factor ceramide-1-phosphate and the unique lysosomal lysolipid bis(monoacylglycero)phosphate. The inherited ASM deficiency, Niemann-Pick disease type A and B, impairs mainly, but not only, cellular sphingomyelin catabolism, causing a progressive sphingomyelin accumulation, which furthermore triggers a secondary accumulation of lipids (cholesterol, glucosylceramide, GM2) by inhibiting their turnover in late endosomes and lysosomes. However, ASM appears to be involved in a variety of major cellular functions with a regulatory significance for an increasing number of metabolic disorders. The biochemical characteristics of ASM, their potential effect on cellular lipid turnover, as well as a potential impact on physiological processes will be discussed.
\end{abstract}

Keywords: acid sphingomyelinase deficiency (ASMD); Niemann-Pick disease; lysosomal phospholipase C; sphingomyelin; membrane lipids; ASM inhibitors; regulation; lipid accumulation; topology; depression

\section{Introduction}

Amphiphilic phospholipids (PLs) and proteins are the main and crucial building blocks of eukaryotic cellular membranes [1,2]. Besides the dominating glycero-PLs, mammalian cell membranes also contain a varying share of sphingolipids, cell type specific glycosphingolipids, and the sphingo-PL sphingomyelin (SM). Their major catabolic pathways occur within the lysosomal system, mostly catalyzed by rather unspecific hydrolases, lipases and glycosidases, sometimes supported by cofactors such as lipid binding proteins (saposins (Saps) and GM2 activator protein (GM2AP)). In the acidic environment of endosomes and lysosomes, complex lipids and other amphiphilic macromolecules are degraded on intralysosomal luminal vesicles (ILVs), and their components are released into the cytosol of the cell as fuel for energy metabolism and substrates for biosynthetic pathways. Whereas different glycero-PLs can be catabolized by rather substrate-unspecific lipases in alternative pathways, sphingolipids of mammalian cells are degraded in a stepwise manner without an effective bypass in human lysosomal catabolism. Therefore, an inherited defect of any catabolic step causes a progressive accumulation of the undegradable sphingolipid substrates, triggering a sphingolipid storage disease. Long before the molecular and metabolic basis of the inherited storage diseases had been elucidated, their clinical picture and fatal pathology was described. Few genotype-phenotype correlations have 
been observed recently in patients with Niemann-Pick disease types A and B [3]. In 1914, pediatrician Albert Niemann in Berlin published a report on a female infant who suffered from a progressive and severe hepatosplenomegaly, passing away at 18 months of age. Her visceral organs were full of foam cells like those in Gaucher disease [4]. Ludwig Pick identified further cases of similar etiology, clearly differentiating them from Gaucher disease [5]. Later, the disease became known as Niemann-Pick disease, a typical lysosomal lipidosis.

By a chemical analysis of postmortem brain tissue, Ernst Klenk identified the amphiphilic lipid SM as the main and primary storage compound in Niemann-Pick disease [6]. It is a major component of the outer leaflet of cellular plasma membranes, especially of neurons. It was first isolated and characterized in 1884 by Johann L. W. Thudichum-who was trained in chemistry by Justus Liebig in Giessen, Germany [7]. A SM-cleaving hydrolase, the SM phosphodiesterase also called acid sphingomyelinase (ASM, E.C. 3.1.4.12) was discovered by Shimon Gatt in 1966 [8] and its deficiency identified by R. O. Brady as the cause of the progressive SM accumulation in Niemann-Pick disease [9]. Autosomal recessive Niemann-Pick disease caused by ASM deficiency is a rare lysosomal storage disorder with a broad disease spectrum that includes chronic visceral (type B) and neurovisceral forms (intermediate type A/B) as well as the infantile, rapidly progressive fatal neurovisceral disease (type A) with type $B$ being the most prevalent [10]

More recently, Niemann-Pick disease type A and B was renamed as ASM deficiency or ASMD to clearly differentiate the underlying pathology from Niemann-Pick disease type $C$ which is caused by an intracellular cholesterol transport defect leading to the accumulation of cholesterol and SM but not by ASM deficiency [11].

The purpose of this comprehensive review is to summarize the main features of human ASM, its biosynthesis, processing and intracellular trafficking, its structure and proposed mode of action at the surface of PL-substrate carrying intraendolysosomal vesicles. Its PL-cleaving activity regulation by membrane lipids and sphingolipid activator proteins, lipid-binding proteins with a broad substrate specificity, will be highlighted. The majority of ASM literature implies that ASM specifically hydrolyses SM as a substrate to generate ceramide and phosphocholine and ignores its ability to degrade further substrates. In vitro experiments with radiolabeled PLs show that more than twenty different PLs are cleaved by ASM including some minor but functionally important PLs such as the unique lysosomal lysolipid bis(monoacylglycero)phosphate (BMP) and the cellular growth factor ceramide-1-phosphate (Cer1P).

The recessively inherited ASMD mainly leads to impaired cellular SM catabolism causing progressive SM accumulation in the cellular membranes. Furthermore, ASM appears to be involved in a variety of major cellular, endolysosomal regulatory functions for an increasing number of metabolic disorders. The biochemical characteristics of ASM, their potential effect on cellular lipid turnover, as well as their potential impact on physiological processes will be discussed.

\section{Biosynthesis, Cellular Processing, Trafficking and Structure of Human ASM}

ASM is a major cellular phosphodiesterase also known as phospholipase C (PLC), cleaving the phosphodiester bond of its PL substrates as shown in Figure 1A for the sphingo-PL SM and the glycero-PL phosphatidylcholine (PC) at low $\mathrm{pH}$ values.

After several unsuccessful attempts in various laboratories, the secretory form of ASM was eventually purified to homogeneity by factor 25.000 from human urine, collected from patients suffering from a cancer breakthrough or heavy traumatic organ damage [12,13]. Its sequencing allowed the decoding of the cDNA-encoding ASM [14,15], which was needed to analyze the molecular basis of ASMD also called Niemann-Pick disease, type A and $\mathrm{B}[16,17]$, and to identify the structural organization of the complete gene that encodes ASM (Figure 1B) [18]. Human ASM is encoded by the SMPD1 gene located in the chromosomal region 11p15.4. The full-length cDNA of ASM contains an open reading frame of $1890 \mathrm{bp}$ encoding 629 amino acids. The mature enzyme was shown to be a monomeric glycoprotein 
containing a protein core of $64 \mathrm{kDa}$. It has eight disulfide bridges [19] and five of the six $\mathrm{N}$-glycosylation sites are occupied [20] (Figure 1B).
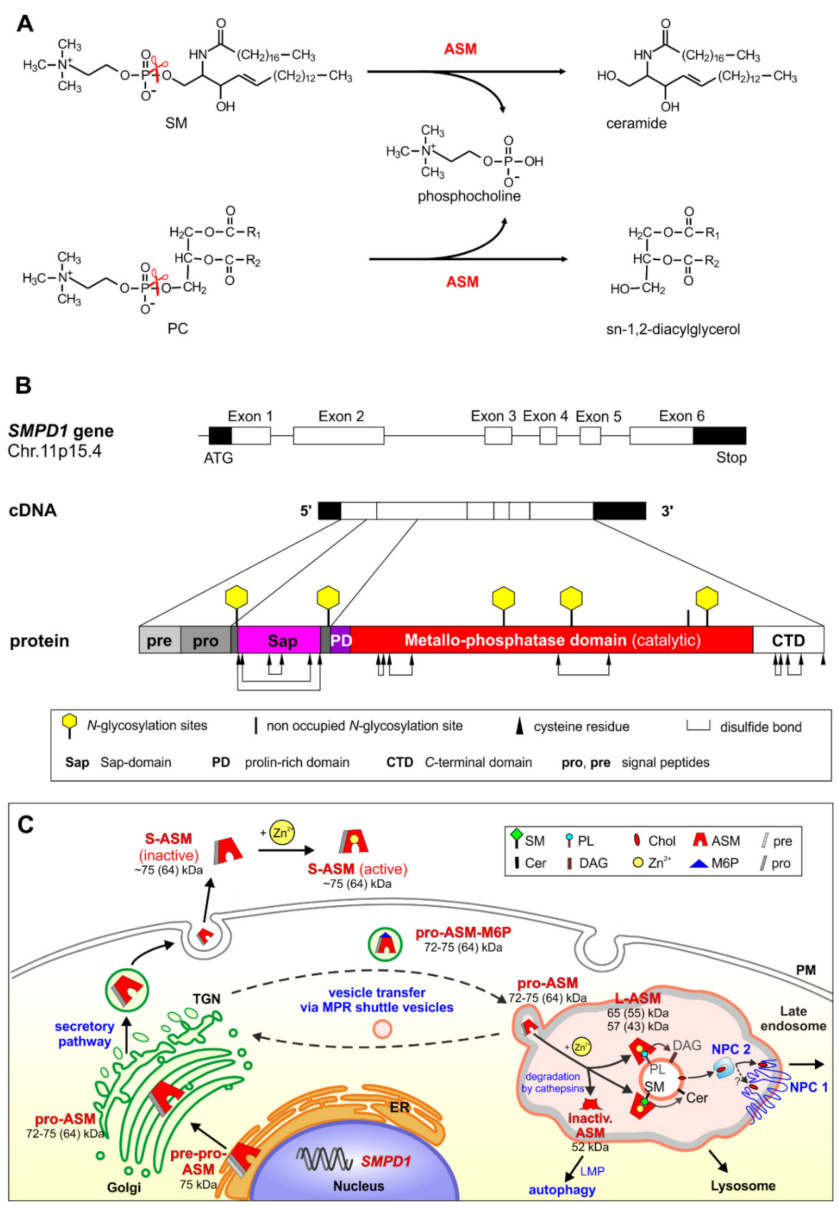

Figure 1. (A) ASM acts as an endolysosomal phospholipase $C$ that cleaves off the phosphocholine residue from sphingomyelin and phosphatidylcholine. (B) Schematic illustration of the gene structure (exons represented in boxes), cDNA and processing structure of human ASM. The gene SMPD1 of the ASM has been mapped to the chromosomal region 11p15.4. Mature human ASM contains several domains: a signal peptide (amino acids 1-46), a Sap-domain (amino acids 89-165), a proline-rich domain (amino acids 166-198), the catalytic metallo-phosphatase domain (amino acids 199-461), and the $C$-terminal domain (amino acids 462-629). $\mathrm{N}$-glycosylation sites and disulfide bridges are shown. (C) Topology of ASM processing. Pro-ASM is generated from pre-pro-ASM within the Golgi and is transported after mannose-6-phosphorylation by mannose-6-phosphate receptor mediated vesicle transfer to the endolysosomal compartments (L-ASM) or exported by the secretory pathway (S-ASM). In the endolysosomal compartment, the pro-ASM matures to the active forms. If L-ASM cannot interact with the intraendolysosomal luminal vesicles, the enzyme is degraded by cathepsins (inactivated ASM). This process leads to higher levels of sphingomyelin, which may disturb membrane homeostasis and cause lysosome membrane permeabilization (LMP), which triggers cell-death by apoptosis and apoptosis-like pathways. The molecular mass given in brakes is the deglycosylated form. ASM: acid sphingomyelinase, Cer: ceramide, Chol: cholesterol, CTD: C-terminal domain, DAG: diacylglycerol, ER: endoplasmic reticulum, L-ASM: lysosomal ASM, LMP: lysosome membrane permeabilization, M6P: mannose-6-phosphate, MPR: mannose-6-phosphate receptor, NPC 2: Niemann-Pick disease protein C type 2, PC: phosphatidylcholine, PD: proline-rich domain, PL: phospholipid, PM: plasma membrane, pre-pro-ASM: pre-pro form of ASM, pro-ASM: pro form of ASM, Sap: Sap-domain, S-ASM: secretory ASM, SM: sphingomyelin, TGN: trans Golgi network. 
The availability of ASM-specific polyclonal antibodies allowed the elucidation of the intracellular processing of human ASM by multiple proteolytic steps (Figure 1C) [21,22]. ASM is first synthesized in the endoplasmic reticulum as a $75 \mathrm{kDa}$ pre-pro-enzyme, which is rapidly processed after signal peptide cleavage to the $72 \mathrm{kDa}$ pro-ASM in the endoplasmic reticulum-Golgi complex. Thereafter, the pro-ASM is transported to endolysosomal compartments or is exocytosed to the extracellular space by the secretory pathway (Figure 1C). The intracellular transfer of ASM and many other lysosomal hydrolases from the trans-Golgi network (TGN) to late endosomes and lysosomes depends on the mannose6-phosphate receptor (M6PR) (Figure 1C), whereas sortilin provides an alternative route for ASM and the lipid binding proteins prosaposin and GM2AP to the phagosome [23-26]. The mature lysosomal ASM is generated by C-terminal proteolytic processing [27]. After cell treatment with cationic amphiphilic drugs (CADs), ASM cannot any longer attach properly to the intraendolysosomal luminal membranes and is rapidly degraded to an inactive form $(52 \mathrm{kDa})$ [28] by cathepsins [29-31]. A second pathway leads to the secretion of ASM into the extracellular space. The major active form secreted has a size of $\sim 75 \mathrm{kDa}$, a minor one of $57 \mathrm{kDa}$ [22]. Both forms of ASM require zinc ions for activity [32].

Mature human ASM contains several domains: a signal peptide (amino acids 1-46), a Sap-domain (amino acids 89-165), a proline-rich linker domain (amino acids 166-198), the catalytic metallo-phosphtase domain (amino acids 199-461), and the C-terminal domain (amino acids 462-629) [33]. Whereas most sphingolipid hydrolases need the help of a lipid binding protein to reach a physiological turnover of (glyco)sphingolipids in the lysosomal compartment (GM2AP or one of the Saps A, B, C or D), the polypeptide of the ASM contains an $\mathrm{N}$-terminal Sap-domain, which maintains basic SM-cleaving activity even in the absence of external sphingolipid activator proteins [34]. Therefore, SM hydrolysis is not significantly affected by the absence of Saps in prosaposin deficient patients and mice [35]. The structure of the Sap-domain of ASM is similar to that of Saps A-D [33]. These proteins can bind to membranes and undergo a conformational change [36,37] from a closed conformation to an open form that allows interaction with anionic charged membranes [38,39].

The catalytic metallo-phosphatase domain contains a binuclear zinc-center at its active site that binds SM with its ceramide-phosphate moiety and triggers a nucleophilic attack of an activated water molecule to split the phosphodiester bond. The catalytic domain contains a binuclear zinc-center at its active site that binds SM with its ceramidephosphate moiety and triggers a nucleophilic attack of an activated water molecule to split the phosphodiester bond. Its cooperation with the flexible Sap-domain is essential for activity $[33,38,39]$ (Figure 1B). This notion is supported by a complete loss of ASM activity in an infantile patient having a point mutation in its Sap-domain. The patient developed a severe form of Niemann-Pick disease type A with hepatosplenomegaly, developmental delay, and rapid neurological deterioration [40]. His fatal lipidosis emphasizes the essential function of the SAP domain for cellular SM turnover. Apparently, the Sap-domain of ASM allows a basal SM turnover in the lysosome even in the absence of any external Saps [41,42]. A basal lipid turnover is also achieved by other hydrolases acting on small membrane-bound sphingolipids in the absence of a sphingolipid activator protein in vitro, like glucosylceramide hydrolysis by $\beta$-glucocerebrosidase encoded by GBA 1 [43] and ceramide degradation by acid ceramidase [44]. However, the turnover achieved in vivo in the absence of Saps is too low to prevent lipid storage [34]. In contrast, the lysosomal breakdown of the complex membrane-bound gangliosides GM1 and GM2 depends heavily on their lipid binding cofactors, GM2AP and Sap B [45-47].

\section{ASM, an Endolysosomal and Secretory Phospholipase C, Cleaving Membrane Lipids}

Most lysosomal hydrolases are unspecific (promiscuous) enzymes and degrade in vivo and in vitro soluble substrates such as oligosaccharides, and insoluble molecules such as membrane-bound lipids and sphingolipids as well as synthetic and fluorescence generating soluble substrates in vitro, often used to assay the overall activity of a hydrolase in biological samples. This overall activity, however, is not identical with the lipid cleaving 
activity of the hydrolase. Its lipid splitting activity is often heavily regulated in a complex manner by features of the lipid-substrate carrying vesicle membrane, by:

(a) the surface potential (measured by zeta potential) of the liposomal vesicles [48], modelling the ILVs of the lysosomal compartment,

(b) the curvature of the membrane vesicles (e.g., the ILVs) [44],

(c) the hydrolysis stimulating lipid binding proteins (the sphingolipid activator proteins) [49],

(d) stimulating lipids, such as BMP $[43,48,50,51]$, and

(e) inhibiting lipids such as SM [43,46,50].

All these factors hardly affect the cleavage of soluble synthetic substrates in a comparable way in vitro, such as the cleavage of fluorescence generating 4-methylumbellyferyl containing soluble molecules, often used in the medical literature to assay the overall hydrolase activity in biological samples.

There is ample evidence that a monogenic defect can trigger a cascade of metabolic errors in lysosomal storage diseases. Besides drugs like CADs [52], the main posttranslational regulators in the endosomal and lysosomal compartment can modify the lipid cleaving activities of lysosomal hydrolases effectively [53]. The lipid composition and lipid functions of cellular membranes are cell-type and organelle specific. For example, cholesterol, SM, and gangliosides are essential stabilizers of many neuronal plasma membrane functions. In the lysosomal compartment, however, $\mathrm{SM}$ and cholesterol are effective inhibitors of several SAPs and of GSL catabolic pathways, including those of ganglioside GM2 and glucosylceramide [49].

The main PL-degrading phospholipases in the endolysosomal compartments are the phosphodiesterase ASM and the lysosomal phospholipase A2 [54]. It has been shown that both the secretory ASM purified from human urine [12] and the ASM purified from human tissue $[55,56]$ not only hydrolyze SM but also various glycerol-PLs such as phosphatidylcholine (PC) and phosphatidylglycerol (PG). Already in 1980, PLC activity had been recognized in a soluble extract of rat liver lysosomes [57] and other tissue [58] with a $\mathrm{pH}$ optimum of $\mathrm{pH} 4.5[57,59,60]$, but the enzyme has never been characterized. However, since this lysosomal PLC activity was also deficient in fibroblast extracts from patients with ASMD, its nature was assumed to be ASM [61]. To support that notion, we studied the hydrolytic capability of a recombinant ASM, thus being free of any contamination by other lysosomal hydrolases. Indeed, ASM has a much broader substrate specificity than expected so far. In a micellar assay system, ASM cleaves 27 sphingo- and glycerol-PLs: Sphingo-PLs (SM, ceramide phosphorylethanolamine, and ceramide-1-phosphate) were degraded to ceramide, lyso-sphingo-PLs (lyso-SM also called sphingosyl phosphorylcholine, lyso-ceramide phosphorylethanolamine also called sphingosyl phosphorylethanolamine, and sphingosine-1-phosphate) to sphingosine (Figure 2A). Sphingo-PLs (such as SM, ceramide phosphorylethanolamine) were hydrolyzed faster by ASM than their glycerol-PL analogues (PC and phosphorylethanolamine) (Figure 2F,G). Glycero-PLs (Figure 2B,E) were hydrolyzed to diacylglycerol, lyso-glycero-PLs (Figure 2C) and BMP to monoacylglycerol (Figure 2B), plasmalogen to 1-alkenyl-2-acylglycerol, lyso-plasmalogen to 1-alkenylglycerol (Figure 2D).

Only the artificial and synthetic PLs dicetylphosphate and 1,2-dioleoyl-sn-glycero-3ethylphosphocholine were not cleaved by ASM (Figure 2E). 

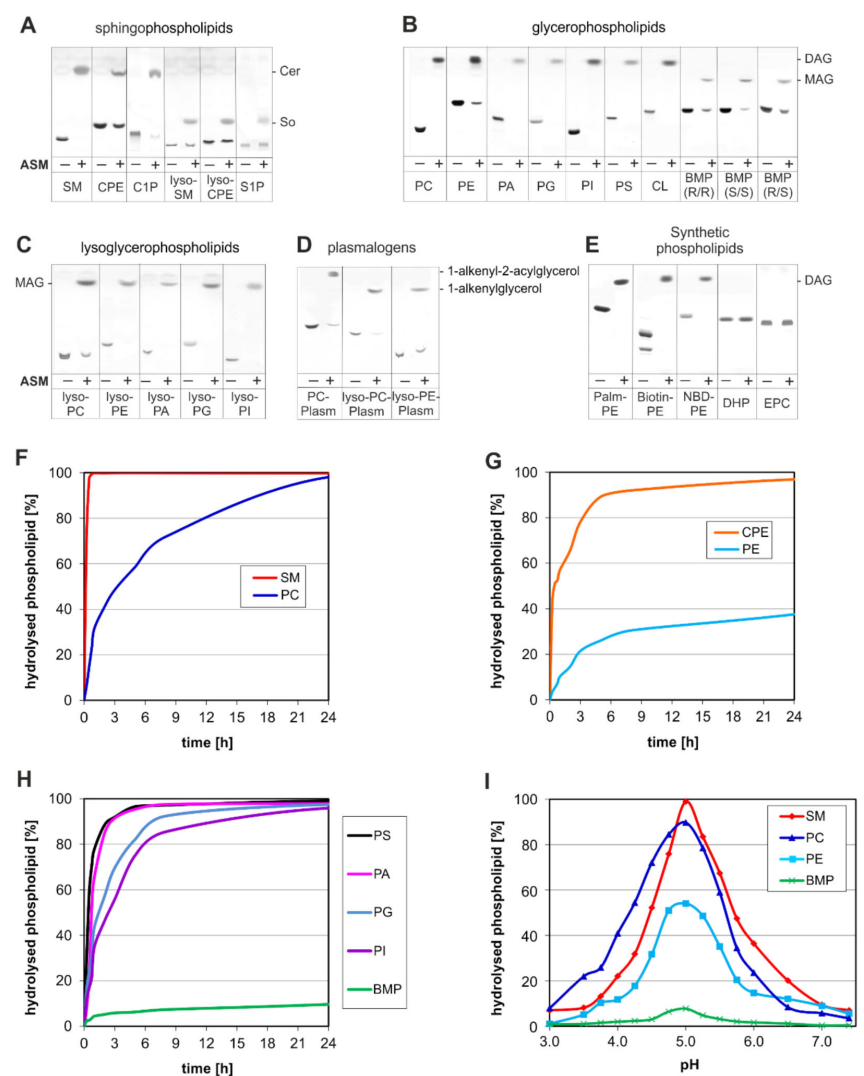

Figure 2. Degradation of phospholipids by recombinant ASM. The ability of ASM to hydrolyze (A) sphingophospholipids, (B) glycerophospholipids, (C) lysoglycerophopholipids, (D) plasmalogens (Plasm) and in (E) synthetic phospholipids ( $N$-palmitoyl-dipalmitoyl phosphatidylethanolamine (Palm-PE), N-biotin-phosphatidylethanolamine, N-NBD-phosphatidylethanolamine and dicetylphosphate (DHP)) was tested in a detergent-based assay. $15 \mu \mathrm{g}$ lipid were incubated in $20 \mathrm{mM}$ sodium citrate buffer containing $0.05 \%$ Triton X 100 (pH 5) in a final volume of $100 \mu \mathrm{L}$ with $10 \mu \mathrm{g}$ recombinant ASM [62] for $24 \mathrm{~h}$ at $37^{\circ} \mathrm{C}$. The reaction was stopped by the addition of $350 \mu \mathrm{L}$ chloroform $/ \mathrm{methanol}$ $1: 2(v / v)$, to obtain a homogeneous phase. For lipid separation by thin-layer chromatography, the chromatograms were developed with chloroform/methanol/water $(60: 25: 4, v / v / v)$ up to $7.5 \mathrm{~cm}$ and twice with n-hexane/diethylether/glacial acetic acid $(70: 30: 1, v / v / v)$ up to the end $(10 \mathrm{~cm})$. To identify the hydrolysis products, standard lipids (ceramide, diacylglycerol, monoacylglycerol, palmitic acid, and sphingosine) were applied. The developed thin-layer chromatography plates were sprayed with an aqueous solution, containing $8 \%(w / v) \mathrm{H}_{3} \mathrm{PO}_{4}(85 \%)$ and $10 \%(w / v) \mathrm{CuSO}_{4}$, and charred at $180{ }^{\circ} \mathrm{C}$ for $10 \mathrm{~min}$. In $(\mathbf{F}-\mathbf{H})$ time dependent and (I) $\mathrm{pH}$ dependent studies, the lipids were incubated under the same conditions as in (A-E), but by varying the time $(0-24 \mathrm{~h})$ or the $\mathrm{pH}$ values of the assay (3.5-7.4) as indicated. For quantitative analytical thin-layer chromatography determination, increasing amounts of standard lipids were applied and the plates were quantified by scanning densitometry at $595 \mathrm{~nm}$. Biotin-PE: N-[6-(biotinoyl)amino]hexanoyl-1,2dihexadecanoyl-sn-glycerol-3-phosphoethanolamine, BMP: bis(monoacylglycero)phosphate, C1P: ceramide-1-phosphate, Cer: ceramide, CL: cardiolipin, CPE: ceramide phosphoethanolamine, DAG: diacylglycerol, DHP: dihexadecyl phosphate also called dicetylphosphate, EPC: 1,2-dioleoyl-snglycero-3-ethylphosphocholine, lyso-CPE: sphingosyl phosphoethanolamine, lyso-PC-Plasm: 1-O-1'(Z)-octadecenyl-2-hydroxy-sn-glycero-3-phosphocholine, lyso-PE-Plasm: 1-O-1'-(Z)-octadecenyl-2hydroxy-sn-glycero-3-phosphoethanolamine, MAG: monoacylglycerol, NBD-PE: N-(7-nitrobenz2-oxa-1,3-diazol-4-yl)-1,2-dihexadecanoyl-sn-glycero-3-phosphoethanolamine, PA: phosphatidic acid, Palm-PE: N-palmitoyl-phosphatidylethanolamine, PC: phosphatidylcholine, PC-Plasm: 1(1Z-octadecenyl)-2-docosahexaenoyl-sn-glycero-3-phosphocholine, PE: phosphatidylethanolamine, PG: phosphatidylglycerol, PI: phosphatidylinositol, PS: phosphatidylserine, S1P: sphingosine-1phosphate, SM: sphingomyelin, So: sphingosine. 
BMP is a unique anionic lyso-PL of the ILVs that effectively stimulates all steps of sphingolipid catabolism in the lysosome which have been analyzed so far and it contributes to generating a negative surface charge on intraendolysosomal vesicle surfaces [49]. In mice, BMP levels apparently adapt to the metabolic state in a cell type-specific manner: they are elevated in hepatocytes and pancreatic cells after fasting [63]. A slow degradation of BMP by an unspecified lysosomal phosphodiesterase activity [64] was observed earlier, which might have originated from ASM activity.

\section{Emerging Functions of ASM, a Promiscuous Phospholipase C, Cleaving Membrane Lipids, Including Cer1P and BMP}

Functional ASM is crucial to prevent not only fatal lysosomal SM storage but also a secondary accumulation of cholesterol, lyso-SM, and glycolipids such as glucosylceramide and gangliosides GM2 and GM3 as observed in ASMD [53,65]. An extensive report on clinical course and autopsy findings of a three year old male patient with neurovisceral pathology was published recently [66]. For the diagnosis of ASMD, the plasma level lysoSM, a biomarker for ASMD, is used [65]. Accumulating SM and cholesterol can attenuate the activity of sphingolipid activator proteins and key steps in lysosomal digestion of macromolecules triggering a cascade of metabolic errors. Furthermore, ASM and the regulation of its SM-cleaving activity are important players to balance the ratio of membrane stabilizing SM and stress signaling ceramide levels properly [67]. Studies on heterozygous and thus partially ASM deficient mice and on wild type mice showed that ASM tempers leukocyte entry into the re-perfused ischemic brain [68]. In addition, experiments including ASM-deficient cells and mice identified ASM as a key player to mediate radiation-induced (a high dose of $15 \mathrm{~Gy}$ ) apoptosis of endothelial cells [69,70]. ASM turned out to be a primary target for radiation-induced apoptosis and tumor shrinkage. These stressors are thought to effectively trigger ASM activity and thereby induce rapidly increasing cellular ceramide levels. Spatially confined increases of membrane ceramide may then lead to the reorganization of lipid rafts and thereby induce corresponding transmembrane downstream signaling [67].

However, the question remains why other major ASM-substrates of cellular membranes such as the PLs, PC and PG, and their metabolites $[12,48]$ are usually not considered in the medical literature and in the molecular model mentioned above as possible players mediating pathophysiological consequences of varying ASM. One reason might be based on the outstanding SM accumulation compared to the relatively minor changes of the glycerol-PL pattern in ASMD. There is indeed one important difference between the catabolic pathways of the ASM substrates. ASM is the only lysosomal phosphodiesterase cleaving the sphingolipid SM, whereas the glycerol-PLs, PC, PG, and many other PLs, can also be degraded by other phospholipases in parallel. Though the lysosomal degradation of PC, PG, and many other PLs generates a greater variety of catabolites than the SM catabolism, ASM deficiency has a much higher impact on SM accumulation than on many other ASM substrates. ASM mediated cleavage of both, membrane-bound SM and PC, is stimulated by anionic PLs such as BMP, PG and phosphatidic acid whereas the lipid metabolites, diacylglycerol, ceramide and free fatty acids, stimulate SM hydrolysis but inhibit PC cleavage (Table 1) [48].

Recent data (Figure 2) underline and further specify the broader substrate affinity of ASM and characterizes ASM as a promiscuous PLC, cleaving besides SM more than 20 membrane lipid species, PLs and lyso-PLs. As depicted in Figure 2A ASM is also capable of cleaving Cer1P, a growth factor on tumor cell surfaces, most likely to the growth inhibitor ceramide. Cer1P is a membrane bound component of the cell surfaces that protects endothelial cells from apoptosis [71,72] and induces proliferation in fibroblasts [73]. Therefore, ASM has the potential to trigger apoptotic as well as proliferative signaling pathways.

An incomplete understanding and narrowed view on ASM as a SM-only specific hydrolase generating ceramide as the one and only important signaling molecule may possibly result in a misleading interpretation and finally wrong conclusion of research data. 
Considering ASM's many physiologically important PL-substrates and their catabolites, we should be cautious not to attribute ASM induced cellular processes solely to changes in SM and ceramide levels as prevailingly stated in the in the medical literature.

Table 1. Regulation of PL cleavage activity of ASM by lipids.

\begin{tabular}{ccccc}
\hline Regulating Lipid & Sphingomyelin & References & Phosphatidylcholine & References \\
\hline BMP & + & {$[42,48]$} & + & {$[48]$} \\
Anionic PLs & + & {$[42,48,74]$} & + & {$[48]$} \\
Cationic lipids/drugs & - & {$[48]$} & {$[$ (BMP) } & {$[48]$} \\
Cholesterol & - & {$[48]$} & - (other anionic lipids) & - \\
Ceramide & $(+)$ & {$[12,48]$} & - & {$[48]$} \\
Diacylglycerol & + & {$[12,48]$} & - & {$[48]$} \\
Fatty acids & + & {$[12,48]$} & & {$[48]$} \\
Monoacylglycerol & + & {$[75]$} & & \\
Phosphatidylinositol-3,5-bisphosphate & - & {$[12]$} & & \\
Phosphatidylinositol-4,5-bisphosphate & - & {$[76]$} & & \\
Phosphatidylinositol-3,4,5-triphosphate & - & {$[77]$} & & \\
Sphingosin-1-phosphate & -1 & &
\end{tabular}

${ }^{1}$ in vivo; +, stimulation; - , inhibition; $\bigcirc$, no effect.

\section{Topology and Regulation of PL-Cleaving Activity of ASM}

Lysosomes have been discovered by de Duve [78] as stomachs of the cell, degrading macromolecules at low pH-values and releasing their components into the cytosol as building blocks for biosynthetic processes and as fuel for energy metabolism. They are now considered as signaling organelles controlling a wide range of cellular functions [79,80]. Complex lipids such as SM and other macromolecules can reach late endosomes and lysosomes by endocytosis $[81,82]$ and also by autophagy and phagocytosis $[47,83-86]$. Plasma membrane-bound biotin- and radio-labeled ganglioside GM1 can reach luminal vesicles of late endosomes and ILVs of the lysosomal system for final degradation as observed by immuno-electron microscopy and metabolic studies [87]. Intraendosomal vesicles and ILVs, membrane-surrounded vesicles within the lumen of the lysosome, are generated by an inward budding of the endosomal perimeter membrane and budding off vesicles into the lumen of the lysosome, as mediated by ESCRT proteins [88]. The components of endosomal perimeter membranes sorted into intraluminal vesicles can be degraded by the digestive juice of late endosomes and lysosomes.

ASM is highly active in the lumen of late endosomes, with its activity peaking around pH 5 (Figure 2I). As a promiscuous PLC, ASM splits SM and many glycero-PLs, which can also be degraded to lyso-PLs by the lysosomal phospholipase A2. This is an important function to avoid a significant accumulation of glycerol-PLs in the absence of ASM in ASMD patients. We assume that in healthy tissue the combined action of ASM and phospholipase A2 easily coverts phospholipids of the outer membrane leaflet of ILVs into micelle-forming lyso-PLs, which then can solubilize and destroy structure and barrier function of the luminal vesicle membranes, generating micelles and other lipid aggregates from both membrane sheets and thus make them all available to the digestive lysosomal juice. Diacylglycerol generated by ASM mediated hydrolysis of glycero-PLs in late endosomes and lysosomes is most likely completely degraded within the acidic compartment of the cell and has probably no chance to escape into the cytosol. Diacylglycerol, however, reaching the cytosolic leaflets of cellular membranes could trigger the release of arachidonic acid from glycero-PLs, the precursor of eicosanoids, a group of local and lipophilic signaling molecules including prostaglandins, prostacyclins, thromboxanes, lipoxins, and leukotriens. 


\subsection{Lipid Sorting and Maturation of ILVs}

ILVs can be easily attacked and digested by the lysosomal juice, whereas the lysosomal perimeter membrane is well protected by a thick and stable glycocalix covering its inner, luminal surface. It prevents hydrolases and lipid binding proteins, the sphingolipid activator proteins, to reach and digest the perimeter membrane. The coat is generated by heavily glycosylated integral membrane proteins with almost digestion resistant polylactosamine units [89].

On the other hand, digestion of ILVs by the lysosomal juice is facilitated considerably by a lipid sorting process leading to a maturation of ILVs mainly at the level of the late endosomes [81,90]. The removal of the stabilizing lipids SM and cholesterol originating from the plasma membrane seems to be essential to reach a physiological turnover rate for many complex glycosphingolipids at the ILVs [53]. For instance, lysosomal accumulation of SM, e.g., in ASMD, triggers a cascade of metabolic errors, first a considerable secondary accumulation of cholesterol by inhibiting its secretion as mediated by the Niemann-Pick protein type C (NPC2) [48]. Both accumulating lipids, SM and cholesterol, are effective inhibitors of several lysosomal lipid binding proteins $[46,50,91,92]$ and key steps in lysosomal sphingolipid catabolism [46,48,93] (Table 2).

Increased SM and cholesterol levels of the intraendolysosomal vesicles (e.g., in ASMD and Niemann-Pick type $C$ disease) inhibit the function of several sphingolipid activator proteins such as GM2AP, Sap A and B $[46,50,91,92]$ and the catabolism of glycosphingolipids, such as ganglioside GM2 and glucosylceramide $[43,46,50]$, which are therefore accumulating secondarily (Table 2). They probably also attenuate the function of further lipid binding proteins (besides NPC2, also Sap C and D) and catabolic steps of complex lipids accumulating in ASMD such gangliosides GM3 [94] and GM2 [95].

Table 2. Storage lipids (SM, cholesterol) in ASM deficiency and their hydrolysis products (ceramide, diacylglycerol) regulate cellular processes.

\begin{tabular}{|c|c|c|c|c|c|}
\hline & Sphingomyelin ${ }^{1}$ & Cholesterol $^{2}$ & Ceramide $^{3}$ & Diacylglycerol $^{4}$ & References \\
\hline \multicolumn{6}{|l|}{ Lipid transfer } \\
\hline Cholesterol transfer by NPC2 & - & & + & & {$[48,96]$} \\
\hline GM1 transfer by GM2AP 5 & - & - & - & & {$[46,50]$} \\
\hline \multicolumn{6}{|l|}{ Membrane solubilization by } \\
\hline Sap A & & - & & & [92] \\
\hline Sap B & & - & & & [91] \\
\hline GM2AP 5 & - & - & + & + & {$[46,50]$} \\
\hline \multicolumn{6}{|l|}{ Lysosomal lipid degradation } \\
\hline GM2 by Hex A/GM2AP 5 & - & - & + & + & {$[46,50]$} \\
\hline GlcCer by GBA1 6 & - & + & + & + & [43] \\
\hline SM by ASM & & 0 & + & + & {$[48]$} \\
\hline \multicolumn{6}{|l|}{ Further cellular processes } \\
\hline Membrane fusion & - & & + & + & [97] \\
\hline
\end{tabular}

${ }^{1}$ primary storage lipid by ASMD, ${ }^{2}$ secondary storage lipid by ASMD,${ }^{3}$ hydrolysis product of $\mathrm{SM},{ }^{4}$ hydrolysis product of glycerol-PLs,

${ }^{5} \mathrm{GM} 2$ activator protein, ${ }^{6} \beta$-glucocerebrosidase; + , stimulation; - , inhibition; $\bigcirc$, no effect.

\subsection{Activation and Inhibition of ASM}

The regulation of the SM-cleaving activity of ASM has been poorly analyzed so far. Due to its Sap-domain, ASM has a basic SM-cleaving activity even in the absence of lipid binding proteins. However, both Sap C [42] (Figure 3C) and Sap D [98], stimulate SMcleavage substantially in vitro. This effect is probably caused by the fusion triggering and membrane destroying properties of Sap C and Sap D [99-104]. Mutations in the Sap-domain of ASM abrogating disulfide bridges or altering the charge are enzymatically inactive in a micellar as well as in a liposomal assay system, even in presence of external Sap C [105]. In vitro studies revealed that anionic lipids in the SM carrying membranes of liposomes boost SM and PC cleavage by ASM effectively, whereas cholesterol strongly inhibits PC but not SM-degradation [48] (Table 1). Catabolism is also directly dependent 
on the curvature of the SM-carrying membrane. As expected, degradation rates of SM were higher in small SM-containing vesicles (SUVs) with a high curvature than in large unilamellar vesicles (LUVs) with a low curvature [42] (Figure 3D).

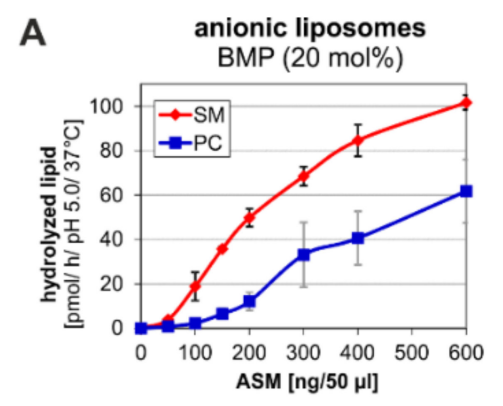

в

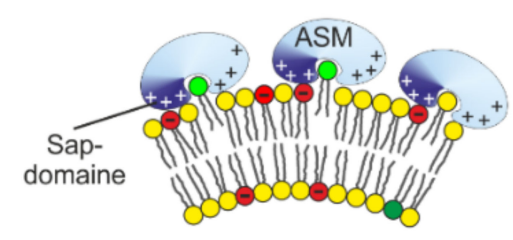

anionic membrane
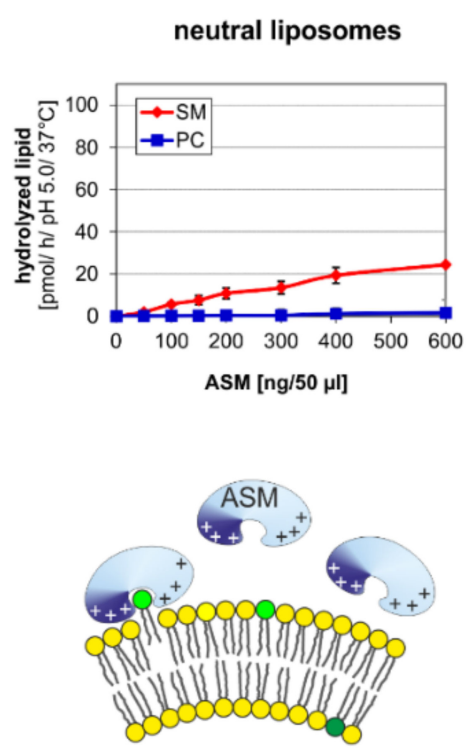

neutral membrane

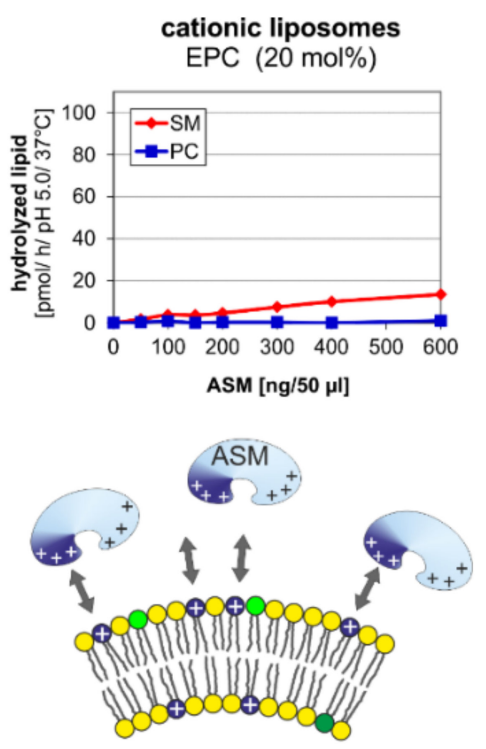

cationic membrane

\section{SM PC anionic lipids $\quad$ cationic lipids or drugs $~ A S M$}

C

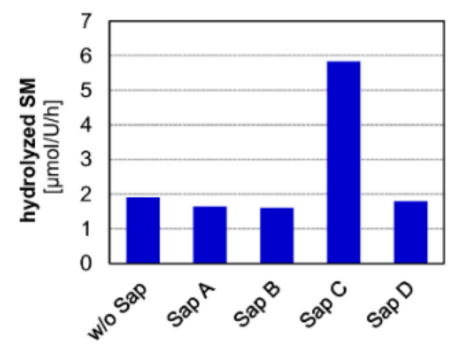

D

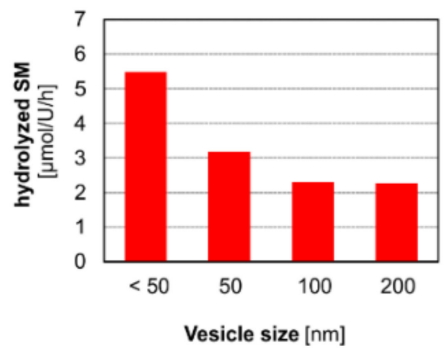

Figure 3. (A) ASM activity on membrane embedded sphingomyelin and phospholipids (e.g., phosphatidylcholine) is stimulated by anionic lipids (e.g., BMP) and inhibited by cationic substances (e.g., 1,2-dioleoyl-sn-glycero-3-ethylphosphocholine (EPC)) [48]. (B, left) The cartoon shows a strong electrostatic binding of cationic ASM to a negatively charged (anionic BMP containing) membrane surface, supporting an ASM mediated hydrolysis of membrane embedded sphingomyelin and other ASM-substrates. (B, middle) shows a decreasing electrostatic attraction, a reduced binding or loose attachment of cationic ASM to a neutral membrane surface reducing the catabolism of sphingomyelin and other phospholipids. (B, right) visualizes a strong electrostatic repulsion between cationic ASM and a positively charged membrane surface containing cationic lipids (EPC), effectively reducing the hydrolysis of membrane embedded SM and other phospholipids by a released ASM, which furthermore may become an easy prey of proteolytic digestion in a lysosomal environment [28]. (B) was modified after [48]. (C) External Sap C treatment and (D) a small vesicle size of negatively charged liposomes stimulates sphingomyelin degradation best. Data are taken from the following publications: (A) [48], (C,D) [42]. ASM: acid sphingomyelinase, BMP: bis(monoacylglycero)phosphate, EPC: 1,2-dioleoyl-sn-glycero-3-ethylphosphocholine, PC: phosphatidylcholine, SM: sphingomyelin.

Several organelle-specific phosphatidylinositolphosphates can affect ASM activity (Table 1). Its SM cleavage is inhibited by $\mathrm{PI}(3,4,5) \mathrm{P}_{3}$ and by $\mathrm{PI}(4,5) \mathrm{P}_{2}$, both located at the plasma membrane, or by $\mathrm{PI}(3,5) \mathrm{P}_{2}$, localized at the perimeter membrane of late endosomes 
and lysosomes [12,75,76], whereas lipids enriched in intraendolysosomal vesicles [106,107] like phosphatidylinositol, BMP and other anionic lipids, enhance ASM activity [42,48].

Based on in vitro studies, BMP and other anionic membrane lipids generate a negative surface potential on liposomal vesicles even at low $\mathrm{pH}$ values, electrostatically attracting protonated lysosomal ASM and other positively charged lysosomal hydrolases to bind to the surface of ILVs in order to effectively facilitate catabolism of their vesicle bound lipid substrates (Figure 3A,B) [48,108]. This electrostatic attraction can be compensated by the incorporation of cationic lipids or CADs into the ILV membranes [48], releasing protonated hydrolases from the substrate carrying ILV membranes (Figure 3B). Endogenous cationic sphingoid bases such as sphingosine and sphinganine inhibit the catabolism of ganglioside GM2 [46], of glucosylceramide [43] at a posttranslational level and presumably also that of SM in ASMD. Many antidepressant drugs such as desipramine and other CADs or synthetic cationic lipids can act as so called "functional inhibitors of ASM" (FIASMAs) [109] (Figure 3A) which is little misleading because it incorrectly implies an ASM specific effect. Due to their physicochemical properties, CADs can easily reach and enter the acidic compartments and accumulate there up to rather high concentrations, thereby significantly increasing the luminal $\mathrm{pH}$ value. This in turn abrogates the electrostatic attraction of various positively charged lysosomal hydrolases to negatively charged ILV-membranes carrying the lipid-substrates to be digested (Figure 3B) [48]. Disruption of the enzymesubstrate interaction by CADs does not only reduce the catabolic rate of PL-cleavage but also leads to premature proteolysis of the released enzymes such as ASM [28,30] (Figure 3B), but also of other hydrolases such as acid ceramidase [110] and due to preliminary evidence for $\beta$-galactosidase and hexosaminidases as well.

Desipramine reduces lysosomal ASM activity in fibroblast culture almost completely, down to few percent within minutes whereas this effect can be halted completely by the preincubation of cells with a protease inhibitor like leupeptin. The more prone an ILVassociated glycoprotein is to proteolytic digestion, the faster its CAD induced depletion. ASM appears to be one of the most proteolysis sensitive proteins resulting in a very fast degradation once detached from ILVs.

Many clinically approved cationic amphiphilic drugs can accumulate in lysosomes of cancer cells. They destabilize their membranes and interfere with their cancer promoting functions opening new possibilities for cancer therapy [111].

\section{ASM Functions within Endosomes and Lysosomes}

As the only SM degrading lipase, functional ASM is essential for the avoidance of a progressive and fatal accumulation of SM and its lyso-derivative, sphingosyl phosphocholinea mitogen [112] — as seen in ASMD. A deficiency of promiscuous ASM in ASMD type A also leads to a percentage increase of BMP in liver similar to that of SM [113], suggesting that ASM is the main enzyme catabolizing lysosomal BMP (Figure 2B,H,I). Furthermore, ASM plays a major role for the maturation of ILVs and the physiological catabolism of many glycosphingolipids.

A main function of ASM is to reduce inhibitory SM levels in intraluminal vesicles in the late endosomes and ILVs in order to establish a physiological rate of cholesterol secretion from the late endosomal compartment and to allow a normal lipid turnover at ILV membranes in the lysosomes [48,107].

Besides a secondary accumulation of cholesterol, the lysosomal SM storage effectively triggers a ganglioside GM2 and glucosylceramide accumulation in ASMD and impedes many catabolic pathways of glycosphingolipids $[48,50]$. Together, cholesterol and SM trigger a cascade of errors in lysosomal lipid metabolism, also impeding all lipid binding proteins tested so far, GM2AP, Sap A and B, and probably also some more. Their inhibition may well cause secondary increases of further glycosphingolipids such as ganglioside GM3 and lactosylceramide [114]. SM also inhibits vesicle fusion, which is facilitated by anionic BMP and ceramide at low $\mathrm{pH}$ values together with lipid binding proteins, NPC2 [48], Sap 
A, C. Supporting this, D. Ruiz-Argüello et al. demonstrated that the in situ generation of ceramide and diacylglycerol leads to vesicle fusion and membrane leakage [97] (Table 2).

Ceramide, generated by an ASM mediated SM breakdown, is a stimulator of many endolysosomal processes e.g., cholesterol transfer by NPC2 [96], activity of glucocerebrosidase [43] and GM2 hydrolysis by $\beta$-hexosaminidase A/GM2AP [46] (Table 2). Ceramide can eventually be converted to Cer1P by ceramide kinase (CERK) for the production of chemokines and cytokines [115]. Cer1P is a signaling lipid, which impacts in the regulation of cell growth and survival, inflammation and tumor dissemination [116]. Ceramides became known as tumor suppressor lipids that trigger apoptotic cell death by acting directly on a voltage dependent anion channel VDAC2 of mitochondria [117].

\section{Can Secreted ASM Act at Cellular Membrane Surfaces Directly?}

Cultured human fibroblasts secrete substantial amounts of an active $75 \mathrm{kDa}$ ASM glycoprotein with a molecular mass of $64 \mathrm{kDa}$ for the peptide chain (Figure 1C). The secretion of ASM is obviously heavily increased in patients stressed by a cancer breakthrough or heavy traumatic organ damage. Their urine served as a source for the first successful purification of ASM to homogeneity [12]. Endothelial cells of mice have been identified as the main source of ASM and ceramide secretion induced by a high, single (15 Gy) radiation dose [118], which triggers apoptosis of endothelial cells [119]. Increased ASM activity and generation of ceramide is a critical response to cell stress. For example, ASM generated ceramide is considered to be a crucial mediator of alveolar destruction in emphysema [120]. A high radiation may raise the instability of endothelial cells and loosen the structure of their membranes [121]. An in vivo assay with fluorescently labeled SM-containing liposomes can be used as a controlled release system of labelled SM in tumor diagnosis after radiation-induced cell stress [122]. The crucial role of increasing ceramide levels generated by activation of ASM during the radiation induced apoptosis of endothelial cells in the central nervous system has been described before [123,124]. However, it is unclear if ceramide is the only and sufficient player to trigger wide-spread apoptosis of endothelial cells. Considering the broad specificity of the promiscuous ASM, cleaving more than 20 PLs besides SM, it is quite likely that the digestion of several constitutional membrane components, Cer1P and the PLs, will substantially contribute to the induction of transbilayer lipid movements [125] and will affect the integrity of some cellular membranes [125]. The secretion of ASM to reach the cellular surface and the extracellular space under normal and stress conditions has been observed already in early studies [12,21,22,126,127].

Therefore, we hypothesize that ASM mediated cleavage of the growth factor Cer1P together with the ASM-triggered extensive breakdown of cellular membrane-lipids could be a plausible cause leading to apoptosis of endothelial cells as observed in tumors of the central nervous system treated with a high single radioactive dose [124].

Intriguingly, the SMPD1 gene coding for ASM of endothelial cells is regulated at the genetic level by the microRNA, miR-15a [121]. A low dose of radiation (2 Gy) upregulates miR-15a and lowers SMPD1 levels, whereas a high dose of radiation (more than $10 \mathrm{~Gy}$ ) lowers miR-15a and activates the SMPD1 gene, increasing ASM biosynthesis. Antidepressant treatment also decreases expression of SMPD1-mRNA [128]. In a similar manner, the NO-donor diethylenetriamine/NO also decreased mRNA and protein expression of ASM in HepG2 cells, triggering apoptosis and cell death [129].

While we know some features of the topology and regulation of ASM activity in late endosomes and lysosomes, little is known about the mechanism and function of secreted ASM acting on PLs of the plasma membrane. So far, no significant levels of ASM stimulating factors have been reported to be present at the cell surface, such as low $\mathrm{pH}$ values, presence of Sap C or anionic PLs like BMP. Molecular dynamics simulations and molecular docking studies suggest that at neutral $\mathrm{pH}$ and also at low $\mathrm{pH}$ below 3.0 ASM adopts a conformational fold making it inaccessible for the binding of SM at the catalytic site, in contrast to the open and accessible ASM structure identified at $\mathrm{pH} 5$ [130]. Of course, local and transient molecular and biophysical changes at the plasma membrane 
may well overcome these activity barriers and stimulate SM and Cer1P cleavage at the cellular surface even by the secreted and soluble ASM. However, no clear evidence is available for SM and Cer1P hydrolysis being directly mediated by secreted ASM at the cellular surface, i.e., on the outer leaflet of intact plasma membranes. Alternatively, lipids of the plasma membrane may cycle back and forth through early endosomes [131], where they could be attacked by ASM at slightly lower $\mathrm{pH}$-values. Secreted ASM seems to be able, at least by an indirect way, to hydrolyze sphingomyelin present at the outer leaflet of cellular membranes to ceramide [132].

On the other hand, atherogenic lipoproteins including SM have been described to be excellent substrates for secreted ASM, even at neutral $\mathrm{pH}$-values. Though secreted ASM can hydrolyze native plasma LDL at pH 5.5, but not at $\mathrm{pH}$ 7.4, LDL modified by oxidation and phospholipase A2 treatment has been reported to be readily hydrolyzed by secreted ASM even at $\mathrm{pH} 7.4$, as reported for atherosclerotic lesions [133].

\section{Medical Importance of Cellular ASM Activity}

ASM is an essential player in the cellular PL metabolism and key for the maturation of intraendolysosomal luminal vesicles. It is a promiscuous lysosomal and secretory PLC, the PL-cleaving activity of which is subject to complex regulation at the genetic and posttranslational level. Changes in ASM activity affect a wide field of the cellular lipid metabolism and may control the fate of the cell, especially the levels of SM and ceramides and in part also the turnover of many other PLs and lyso-PLs. Inherited ASMD, but also variations of ASM activity as controlled by posttranslational regulation, can contribute to neurodegenerative and systemic disorders. They may change the cellular and organellar balance between SM and ceramide levels and modify the PL and lipid pattern of many membranes in a cell-specific manner. The underlying regulatory mechanisms are only poorly understood. Since lysosomal sphingolipid catabolism follows a strictly sequential and stepwise pathway and ASM is the only lysosomal phospholipase degrading SM (and possibly also the sphingolipids ceramide phosphoethanolamine, lyso-SM, and lyso-ceramide phosphoethanolamine), its activity has a direct impact on the molecular ratio between SM and ceramide. This is obviously different for many glycerol-PLs, lysoglycero-PLs and plasmalogens degraded by ASM as given Figure 2A-E. The catabolism of glycerol-PLs usually does not follow a single, exclusive pathway. They can be degraded by different phospholipases, ergo by multiple pathways simultaneously. In other words, if one pathway is deficient, a bypass can compensate at least partially. Nevertheless, it is expected that a downregulation of ASM activity will not only affect cellular SM and ceramide levels, but to some extent also glycerol-PLs and their pattern in cellular membranes.

ASM activity is also important for several intracellular signaling pathways, for example the chemotherapy induced generation of ROS injury [134], the promotion of ferroptosis [135] and the vascular calcification [136].

The complex regulation of PL-cleaving ASM activity can hardly be mimicked by in vitro assays [42]. In vitro assays do not reflect the in vivo lipid cleaving activity of a hydrolase, especially if a soluble synthetic substrate is used. For example, the hydrolysis of soluble 4-methylumbelliferyl-6-sulfo-2-acetamido-2-deoxy- $\beta$-d-glycopyranoside (MUGS) by $\beta$-hexosaminidase $A$ is not affected by effective stimulators and inhibitors of its ganglioside GM2 cleaving activity [46]. Furthermore, CADs and storage compounds accumulating in lysosomal diseases can inhibit GM2 breakdown effectively, but hardly the hydrolysis of soluble substrates like MUGS in vitro [52,53,93].

\section{Assays for Studies of ASM Inhibitors}

In vitro ASM activity assays can demonstrate the presence of ASM in biological samples quantitatively, but they cannot determine its lipid substrate degrading potential in vivo (SM, PC, Cer1P, phosphatidylethanolamine and many others). However, the use of ASM specific inhibitors, e.g., in cultured cells followed by a lipid analysis mass spectrometry can at least identify and quantify lipid-levels affected by reduced ASM activity. 
In cell culture, CADs such as desipramine, chloroquine, propranolol and many others, reduce the lipid cleaving activity of ASM effectively, and that of other lysosomal hydrolases [28,52]. This decline in lipid cleaving activity, however, is neither caused by direct inhibition of the ASM enzyme nor is it specific for ASM. As described in Section 5.2, CADs reduce the electrostatic attraction between protonated and positively charged lysosomal hydrolases and their sphingolipid-substrate carrying ILV-membranes. Based on their physicochemical properties, CADs concentrate in ILV-membranes, decreasing or even abolishing their negative surface potential, needed to attract the catabolic enzymes and protein cofactors.

On the other hand, the development of specific ASM small molecule inhibitors has made great progress recently. Together with a genetic silencing of the SMPD1 gene coding for ASM, they may help to develop tools for analyzing changes of cellular lipid and PL pattern caused by a reduction of ASM activity in more detail.

Unfortunately, SM has been considered in the literature to be the only PL substrate of ASM and together with its product ceramide to be the only membrane lipid affected directly by changes of ASM activity, despite the broad substrate spectrum observed in vitro, identifying ASM as a promiscuous PLC (Figure 2). An ASM mediated breakdown of major glycerol-PLs like PC, phosphatidylethanolamine, phosphatidylserine, phosphatidylinositol, PG, phosphatidic acid, BMP and many more as observed in vitro (Figure 2) should labilize the bilayer structure of intraendolysosomal luminal membranes and allow the digestion of lipid components of the inner leaflet of intraendolysosomal vesicles within the lysosomal compartment. The broad spectrum of ASM substrates as defined in vitro (Figure 2) strongly suggests the digestion of the signaling PL Cer1P and others such as ceramide phosphoethanolamine, lyso-SM, lyso-ceramide phosphoethanolamine, and of many glycerol-PLs in vivo by ASM (Figure 2).

In order to study the role of ASM in diseases such as sepsis, acute lung injury or metastasis of melanoma cells, a promising and specific FRET (Förster resonance energy transfer) based assay has been developed to monitor ASM activity in living cells [137-139]. Recently, the same group also developed a photocaged inhibitor of ASM with O-nitrophenyl photocages and butyryl esters to mask hydroxyl groups transiently. The potent light-inducible inhibitor allows a time-resolved inhibition of ASM activity in intact living cells [140].

An interesting two-component liposome-based colorimetric assay has been described for a neutral bacterial sphingomyelinase. It is rather fast, specific, and more sensitive than currently available commercial tests [141]. It is therefore suitable for a rapid screening of sphingomyelinase inhibitors and can probably easily be adjusted to also screen inhibitors of human ASM at low pH-values.

Small functional inhibitors of ASM have been described [142-144]. A novel and selective small inhibitor for ASM, a N-hydroxy-3-alkoxybenzamide, showed anti-apoptotic and anti-inflammatory activity. It presumably binds key residues and the $\mathrm{Zn}^{2+}$ cofactor of the ASM protein [145]. Another direct inhibitor of ASM (compound 21b) was developed to improve depression-like behaviors of rats [146]. Apparently Avicin G is a potent inhibitor of both, the neutral sphingomyelinase of the plasma membrane and the lysosomal ASM. It depletes both, phosphatidylserine and cholesterol, from the inner leaflet the plasma membrane and mis-localizes K-Ras [147]. An interesting, apparently active site directed small molecule is ARC39 (1-aminodecylidene-bisphosphonic acid), which inhibits lysosomal ASM in intact living cells [148]. The transfusion of ARC39-treated or ASM-deficient aged platelets have lower ceramide levels and alleviate lung injury, compared to wild-type platelets. ASM is also associated with the pathogenesis of lung diseases such as cystic fibrosis and acute lung injury, since ASM deficient mice showed better lung mechanics and were protected from bronchial asthma TH2-regulated allergic bronchial asthma model [149].

The baseline of cellular ASM activity is important to maintain and regulate lysosomal functions properly. ASM is not only needed to allow maturation of ILVs by degrading inhibitory SM and thereby facilitate the secretion of inhibitory cholesterol from the lysosome as discussed above in Section 5, but also functions to maintain physiological mTOR signal- 
ing and to inhibit autophagy. The downregulation of ASM activity reduces and modifies signaling by the lysosomal nutrient-sensing complex (LYNUS), increases autophagy and decreases the levels of sphingosine and sphingosine-1-phosphate [150]. Antidepressant drugs and CADs such as the "functional ASM inhibitors" fluoxetine and amitriptyline, can trigger a slow accumulation of SM, cholesterol and other lipids in the lysosome, and induce autophagy (Figure 1C) for instance in hippocampal neurons [151] and furthermore in glioma cells by pimozide and loperamide. Recently, it was shown that ASM plays an important role in ferroptosis, an iron-dependent cell death which is genetically and biochemically distinct from other forms of regulated cell death [135].

ASM also plays a major role in the development of many other disorders such as cardiovascular and metabolic diseases. Its downregulation was reported to alleviate vascular endothelial insulin resistance in diabetic rats [152] and improve vascular dysfunction in diabetic mice [153]. Amitriptyline inhibits nonalcoholic steatohepatitis and atherosclerosis as induced by high-fat diet and lipopolysaccharide in mice [154]. The survival of cultured oligodendrocytes treated with glutamate was enhanced by the downregulation of ASM-expression as well as by blocking ASM activity [155]. Partial genetic inhibition of the increased ASM levels observed in cultured neurons derived from familial Alzheimer patient with lysosomal depletion restored an autophagic dysfunction by recovering lysosomal biogenesis [156]. Inhibition of upregulated ASM in primary multiple myeloma cells by the functional inhibitor amitriptyline increased the sensitivity to antimyeloma drugs [157]. Upregulation of SM turnover in isolated neuronal plasma membranes may also play a critical role in the action of general anesthetics. The treatment of isolated nerve ending membranes with halothane or xenon gas increased the hydrolysis of membrane-bound $\mathrm{SM}$ by membrane-bound (presumably neutral) sphingomyelinase at neutral $\mathrm{pH}$-values coinciding with increasing membrane fluidity. Already, clinical concentrations of halothane increased SM hydrolysis significantly, and this effect could be enhanced further up to 10-fold by raising halothane concentrations [158]. General anesthetics such as halothane and $\mathrm{N}_{2} \mathrm{O}$-gas also increase the breakdown of membrane-bound ganglioside GD1a by membrane-bound sialidase in parallel to increasing membrane fluidity [159].

\section{Major Depression and the Emerging Role of ASM and Acid Ceramidase in Lysosomal Lipid Turnover}

Major depressive disorder is a global contributor to disability and mortality. The proposed mechanisms of depression are many-fold but poorly established. Antidepressant drugs such as desipramine, fluoxetine, a serotonin reuptake inhibitor, and amitriptyline are thought to increase serotonergic and other neurotransmitter levels in the synaptic cleft of nerve endings. They and many other antidepressant drugs are amphiphilic lipid-like and positively charged CADs, that can concentrate in luminal vesicles of the endolysosome and compensate their negative surface charge. Thereby, positively charged lysosomal hydrolases like ASM, acid ceramidase, hexosaminidases and many others are released and separated from their substrate-carrying membranes and become proteolytically degraded by the lysosomal juice. The breakdown of the electrostatic attraction between positively charged ASM, acid ceramidase, hexosaminidases, and other lysosomal catabolic proteins and their lipid-substrate carrying ILVs, triggers a cascade of functional inhibition of the lysosomal catabolism of SM, ceramide and many other membrane lipids $[47,52,53,93]$. Aberrant levels of ceramide and other sphingolipids have been observed in few cases of depression [160]. On the other hand, antidepressant CADs can trigger a slow increase of lysosomal SM levels and of sometimes lipotoxic ceramide levels in ER-membranes inducing autophagy, especially in hippocampal neurons [151]. Fluoxetine increases hippocampal neurogenesis [161], amitriptyline, and fluoxetine support neuronal proliferation which is mainly mediated by a functional attenuation of lysosomal turnover of SM and other lipids [162,163]. A chronic administration of the serotonin reuptake inhibitor paroxetine and the noradrenaline reuptake inhibitor desipramine reduced sphingosine levels in the prefrontal cortex and paroxetine reduced sphingosine and ceramide levels in the hippocampus, but not sphingosine in the plasma samples. At the genetic level, the drug-induced decrease 
of small sphingolipids such as sphingosine and ceramide, coincided with a reduction of mRNA levels of the SMPD1 gene for ASM and the ASAH1 gene for acid ceramidase [164]. The inhibition of ASM, and therefore an expected slow increase of the SM level, seems to be also an important effect of many antidepressants, a view supported by findings obtained with a newly developed specific ASM inhibitor. Its administration improved depressionlike behaviors in rats and increased hippocampal neurogenesis [146]. On the other hand, the overexpression of ASM in the forebrain of male mice caused a depressive-like phenotype, whereas in female mice, ASM overexpression triggered a social anxiogenic-like behavior [165]. Supporting this, possibly the activities of both sphingomyelinases and ceramidases were elevated in the brain regions of female rats selectively bred for high versus low anxiety-like behavior. High anxiety rats exhibited increased activity of ASM and neutral sphingomyelinase as well as of acid ceramidase and neutral ceramidase in multiple brain regions associated with anxiety and depressive-like behavior [166]. The functional ASM-ceramide pathway in the rat brain has also been implicated in the extinction of learned behavior-coincided with a reduction of ASM activity and decline of ceramides in dorsal hippocampus-and expression of re-learning-related behavior [167].

ASM levels increase with stress, age, and bacterial infections [168] and the downregulation of the ASM gene SMPD1 is associated with resistance to chemotherapy regimens [169]. An indirect functional inhibition of ASM phospholipid-cleaving activity by the CAD amitriptyline prevented harmful behavioral and neurologic effects of repetitive mild traumatic brain injury in mice [163].

\section{Experimental Therapeutic Approaches for Niemann-Pick Disease Types A and B}

Since the pioneering work of R.O. Brady on enzyme replacement therapy (ERT) of patients with adult Gaucher disease, this and few other lysosomal storage diseases not affecting the brain can be successfully treated by this approach [170]. High doses of therapeutic enzyme activity are often applied, in order to reach and to digest storage material in most, even hardly accessible places of the body except those beyond the blood/brain barrier. An ERT with recombinant ASM, olipudase alfa, as treatment option for patients with ASMD type B or neurovisceral type A/B is under development. The most recently presented data from the ASCEND and ASCEND-peds phase II/III trials show a significant improvement of lung diffusion capacity $\left(\mathrm{DL}_{\mathrm{CO}}\right)$ as well as spleen volume reduction compared to the placebo [171]. However, since enzyme replacement therapy with high dose ASM in ASMD patients may cause toxic side effects by abruptly changing the cellular balance between SM, ceramide, and other PLs, a dose escalation strategy with olipudase alfa has been successfully developed $[172,173]$. Another interesting experimental approach to improve targeting and dosing was published recently [174]. Here, the therapeutic recombinant human ASM was loaded into liposomal formulations which reduced the accumulation of toxic lyso-SM in Niemann-Pick disease type B fibroblasts by $71 \%$.

However, whether recombinant human ASM also changes levels and pattern of other sphingolipid and glycerol-PL substrates significantly and thereby affects other cellular processes is currently unknown. Of special interest are known ASM-substrates such as BMP, Cer1P, cardiolipin, ceramide phosphorylcholine, lyso-ceramide phosphorylcholine, phosphatidic acid, lyso-phosphatidic acid, lyso-SM, PC, lyso-PC, phosphatidylethanolamine, lyso-phosphatidylethanolamine, PG, lyso-PG, phosphatidylinositol, lyso-phosphatidylinositol, and phosphatidylserine.

\section{The Role of ASM in Bacterial, Mycobacterial, Fungal, and Viral Infections}

The generation of ceramide at the expense of SM by the sphingomyelinases, ASM, and neutral sphingomyelinase, is a key factor for the internalization, damaging, and killing of diverse pathogens, bacteria, and mycobacteria, such as Staphylococcus-aureus, Chlamydiatrachomatis, Neisseria-meningitis, Listeria-monocytogenes, and Pseudomonas-aeruginosa, Neisseria-gonorrhoeae, and has been reviewed recently [175,176]. ASM also contributes to the control of Mycobacterium bovis Bacillus Calmette-Guerin infection of murine macrophages [177]. 
On the other hand, the functional inhibition of ASM activity stops infection cycles of vacuole adapted bacteria such as Anaplasma-phagocytophilum, Chlamydia trachomatis, and Chlamydia pneumoniae or even kills Coxiella burnettii $[109,178]$. ASM is also an essential regulator of mucosal immunity to enteric pathogens. Mice with ASM deficiency or functional inhibition of ASM were highly susceptible to an infection by a Citrobacter rodentium-driven colitis [179].

Fungal infections are a global health threat with high morbidity. Recent discoveries were reviewed by Guzman et al. [180]. They shed insight on the mechanisms of fungal infections and on host lipids involved, including SM and ceramide and their role in phagocytotic uptake and clearance of fungal pathogens. The cellular mechanism of pathogen internalization, followed by inflammatory signaling and induced fibrosis are reviewed in [181].

Also, enveloped viruses often enter cells by endocytic pathways [182], such as rhinovirus, influenza A virus, Ebola virus, Lassa virus, and in part also SARS-CoV-2. The acidic $\mathrm{pH}$ of the endolysosomal compartment is crucial for the release of the viral RNA into the host cytosol [182]. It has been demonstrated that ASM activity as well as the SM and cholesterol homeostasis are important factors of the infection process. In the case of an influenza A virus infection, the accumulation of cholesterol in the endolysosomal compartment contributes to the interferon-induced attenuation of viral RNA release into the host cytosol [183]. An increased cholesterol level, either due to a primarily increased SM level or another reason, can also impair the infection by the Ebola virus and the novel virus SARS-CoV-2 [184-186]. Hence, it is not surprising that SARS-CoV-2 is inhibited by cationic amphiphilic antidepressant drugs, such as amitriptyline and fluoxetine, in vitro [187-189]. Both inhibit the endolysosomal cleavage of SM by ASM. This effect can also be observed for a lot of other viruses $[190,191]$. CADs seem to be promising tools to develop antiviral drugs. Unfortunately, such in vitro observations often cannot be confirmed by in vivo studies. However, in the case of SARS-CoV-2 infection the use of antidepressant CADs reduced the risk of intubation or death in hospitalized COVID-19 patients [192,193].

It has been furthermore suggested that the unique anionic lysosomal lipid BMP plays an important role in viral infections [194] and that the secretory ASM is required for the virus entry at the plasma membranes [190], reducing their high SM levels and leading to an internalization of the virus [195]. It has also been shown that sphingosine could be exploited as an antiviral compound. In the case of SARS-CoV-2-infection, sphingosine binds to the ACE2 receptor and prevents the interaction of the virus with the cellular receptor [196].

\section{Conclusions and Perspectives}

ASM appears to be the predominant lysosomal PLC. It cleaves SM along with many other PLs at surfaces of luminal intraendolysosomal vesicles and is key for the PL degradation in late endosomes and lysosome. The PL-cleaving activity of ASM is stimulated by Sap C [42] (Figure 3C) and by Sap D [98] and by anionic lipids of the substrate carrying luminal vesicles such as BMP (Figure 3, Table 1). In ASMD and few other LSDs such as mucopolysaccharidoses (Hurler, Hunter, Sly, and Sanfilippo syndrome) catabolic pathways can be inhibited by primary lysosomal storage compounds, which often trigger a cascade of secondarily accumulating lipids, aggravating the clinical course of the disease.

The hydrolysis of membrane-stabilizing SM is key for lysosomal lipid sorting and lipid digestion. An inherited deficiency of ASM in ASMD causes a major SM accumulation, which triggers a cascade of catabolic dysfunction. Accumulating SM in late endosomes and lysosomes blocks cholesterol secretion from late endosomes by inhibiting the cholesterol transfer protein NPC2, even in the presence of anionic lipids such as BMP $[48,96]$, leading to a massive secondary accumulation of cholesterol in ASMD [197]. Both SM and cholesterol inhibit various lysosomal processes, whereas the degradation products of ASM action (ceramide and diacylglycerol) are stimulators for many lysosomal and cellular processes (see Table 2). The PL-cleaving activity of ASM controls the balance of the SM and ceramide ratio to a major extent in many cellular membranes. As secreted PLC, ASM is furthermore considered to turnover PLs of extracytosolic membrane-leaflets, including cellular surfaces. 
Therefore, ASM is an important player in cellular homeostasis. An unbalanced SM/ ceramide ratio can lead to cell stress and apoptosis.

The treatment of cultured cells and animals with CADs leads to an accumulation of undegraded lipids in ILVs. Based to their physicochemical properties, CADs reach luminal vesicles in late endosomes and lysosomes, compensate their negative surface charge, and reduce the electrostatic attraction of positively charged hydrolases to the membranes of ILVs. Hydrolases like ASM can be released from the ILV surfaces into the lumen of the lysosomes where they are easily degraded like ASM by lysosomal proteases $[28,48]$. The digestion of ASM should lead to even higher levels of SM, which may disturb membrane homeostasis and cause lysosome membrane permeabilization, which triggers cell-death by apoptosis and apoptosis-like pathways.

Due to the broad specificity of the promiscuous ASM towards sphingo-PLs and glycero-PLs, we propose the hypothesis that secretory ASM also plays an important role by cleaving the growth factor Cer1P. This, together with the massive release of ASM from endothelial cells, could explain the apoptotic cell death of tumors of the central nervous system after a single treatment with a high radioactive dose. ASM substrates such as sphingo-PLs and glycero-PLs including their lyso-derivatives and ASM mediated lipid products such as ceramide and diacylglycerol, play a substantial role in metabolic pathways of medical importance, especially in major depression, in bacterial and fungal infections, and in the regulation of lysosomal catabolism.

The molecular mechanisms regulating ASM activity at membranes of subcellular organelles are only poorly understood. Multiple stimuli regulating ASM activity are known, such as lipid composition of organellar membranes, direct oxidation of membrane components, irradiation, bacterial and viral infection, proteolytic digestion of proteins, etc.

We hypothesize that membrane lipids are not only simple building blocks of organellar membranes-like bricks of a wall—but that many of them have rather important regulator and signaling functions for metabolic pathways occurring at organellar membranes and within the organellar lumen as discussed above for the generation of secondary storage compounds by primarily accumulating membrane lipids (e.g., primarily accumulating SM triggers cascades of secondarily accumulating lipids, cholesterol, ganglioside GM2, glucosylceramide and many others). They are supposed to regulate and modify activities of organellar proteins, e.g., of enzymes and receptors. Pathological changes of the cellular lipid composition may well mis-regulate cellular metabolism, especially lipid and membrane metabolism in obesity, Alzheimer and Parkinson disease. Therefore, lipid pattern of organelle membranes should be analyzed in situ, with high spatial and temporal resolution, which is currently not possible. The currently available techniques for lipidomics of tissues and cultured cells are of little value due to their insufficient spatial resolution. Data obtained on cellular lipid distribution are averaged over many quite different submicroscopic organellar structures. Future developments will hopefully bring tools to determine organelle-specific lipid patterns and elucidate the specific regulatory functions of membrane composition.

Author Contributions: B.B. and K.S. wrote this manuscript. Both authors have read and agreed to the published version of the manuscript.

Funding: Studies in the authors' laboratory were supported by Fonds der Chemischen Industrie (161382) and German research foundation (DFG) (SFB 645, SA 257-24-2), and we thank Sanofi-Aventis Deutschland $\mathrm{GmbH}$ for the financial support for writing this review.

Institutional Review Board Statement: Not applicable.

Informed Consent Statement: Not applicable.

Data Availability Statement: Not applicable.

Acknowledgments: The authors thank Stephanie Lansmann for purified recombinant ASM, which was used for the studies in Figure 2. We also thank Christina Schütte (Pro-Sciencia, Lübeck, Germany) for helpful corrections and discussions. 
Conflicts of Interest: The authors declare no conflict of interest.

$\begin{array}{ll}\text { Abbreviations } \\ \text { ASM } & \text { Acid sphingomyelinase } \\ \text { ASMD } & \text { Acid sphingomyelinase deficiency } \\ \text { BMP } & \text { Bis(monoacylglycero)phosphate } \\ \text { CAD } & \text { Cationic amphiphilic drugs } \\ \text { Cer1P } & \text { Ceramide-1-phosphate } \\ \text { GM2AP } & \text { GM2 activator protein } \\ \text { ILV } & \text { Intralysosomal luminal vesicles } \\ \text { NPC2 } & \text { Niemann-Pick disease protein C type 2 } \\ \text { PC } & \text { Phosphatidylcholine } \\ \text { PG } & \text { Phosphatidylglycerol } \\ \text { PL } & \text { Phospholipid } \\ \text { PLC } & \text { Phospholipase C } \\ \text { Sap } & \text { Saposin } \\ \text { SM } & \text { Sphingomyelin }\end{array}$

\section{References}

1. Van Meer, G.; de Kroon, A.I. Lipid map of the mammalian cell. J. Cell Sci. 2011, 124, 5-8. [CrossRef]

2. Van Meer, G. Cellular lipidomics. EMBO J. 2005, 24, 3159-3165. [CrossRef]

3. Hu, J.; Maegawa, G.H.B.; Zhan, X.; Gao, X.; Wang, Y.; Xu, F.; Qiu, W.; Han, L.; Gu, X.; Zhang, H. Clinical, biochemical, and genotype-phenotype correlations of 118 patients with Niemann-Pick disease Types A/B. Hum. Mutat. 2021, 42, 614-625. [CrossRef]

4. Niemann, A. Ein unbekanntes Krankheitsbild. Jahrb. Kinderheilkd. 1914, 79, 1-10.

5. Pick, L. Über die lipoidzellige Splenohhehatomegalie typus Niemann-Pick als Stoffwechselerkrankung. Med. Klin. 1927, 23, 1483-1486.

6. Klenk, E. Niemann-Pick'sche Krankheit und Amaurotische Idiotie. Hoppe-Seyler's Z Physiol. Chem. 1939, 262, 128-143. [CrossRef]

7. Thudichum, J.L.W. A Treatise on the Chemical Constitution of the Brain; Bailliere, Tindall and Cox: London, UK, 1884.

8. Barnholz, Y.; Roitman, A.; Gatt, S. Enzymatic hydrolysis of sphingolipids. J. Biol. Chem. 1966, 241, 3731-3737. [CrossRef]

9. Brady, R.O.; Kanfer, J.; Mock, M.; Fredrickson, D. The metabolism of sphingomyelin. Evidence of an enzymatic deficiency in Niemann-Pick disease. Proc. Natl. Acad. Sci. USA 1966, 55, 367-370. [CrossRef]

10. Schuchman, E.H.; Desnick, R.J. Niemann-Pick disease types A and B: Sphingomyelinase deficiencies. In The Metabolic and Molecular Bases of Inherited Disease, 8th ed.; Scriver, C.R., Beaudet, A.L., Sly, W.S., Valle, D., Eds.; McGraw-Hill: New York, NY, USA, 2001; pp. 3589-3610.

11. Vanier, M.T. Complex lipid trafficking in Niemann-Pick disease type C. J. Inherit. Metab. Dis. 2015, 38, 187-199. [CrossRef]

12. Quintern, L.E.; Weitz, G.; Nehrkorn, H.; Tager, J.M.; Schram, A.W.; Sandhoff, K. Acid sphingomyelinase from human urine: Purification and characterization. Biochim. Biophys. Acta (BBA)-Lipids Lipid Metab. 1987, 922, 323-336. [CrossRef]

13. Quintern, L.E.; Zenk, T.S.; Sandhoff, K. The urine from patients with peritonitis as a rich source for purifying human acid sphingomyelinase and other lysosomal enzymes. Biochim. Biophys. Acta 1989, 1003, 121-124. [CrossRef]

14. Quintern, L.E.; Schuchman, E.H.; Levran, O.; Suchi, M.; Ferlinz, K.; Reinke, H.; Sandhoff, K.; Desnick, R.J. Isolation of cDNA clones encoding human acid sphingomyelinase: Occurrence of alternatively processed transcripts. EMBO J. 1989, 8, 2469-2473. [CrossRef]

15. Schuchman, E.H.; Suchi, M.; Takahashi, T.; Sandhoff, K.; Desnick, R.J. Human acid sphingomyelinase. Isolation, nucleotide sequence and expression of the full-length and alternatively spliced cDNAs. J. Biol. Chem. 1991, 266, 8531-8539. [CrossRef]

16. Ferlinz, K.; Hurwitz, R.; Sandhoff, K. Molecular basis of acid sphingomyelinase deficiency in a patient with Niemann-Pick disease type A. Biochem. Biophys. Res. Commun. 1991, 179, 1187-1191. [CrossRef]

17. Levran, O.; Desnick, R.; Schuchman, E. Niemann-Pick disease: A frequent missense mutation in the acid sphingomyelinase gene of Ashkenazi Jewish type A and B patients. Proc. Natl. Acad. Sci. USA 1991, 88, 3748-3752. [CrossRef]

18. Schuchman, E.H.; Levran, O.; Pereira, L.V.; Desnick, R.J. Structural organization and complete nucleotide sequence of the gene encoding human acid sphingomyelinase (SMPD1). Genomics 1992, 12, 197-205. [CrossRef]

19. Lansmann, S.; Schuette, C.G.; Bartelsen, O.; Hoernschemeyer, J.; Linke, T.; Weisgerber, J.; Sandhoff, K. Human acid sphingomyelinase. Eur. J. Biochem. 2003, 270, 1076-1088. [CrossRef] [PubMed]

20. Ferlinz, K.; Hurwitz, R.; Moczall, H.; Lansmann, S.; Schuchman, E.H.; Sandhoff, K. Functional characterization of the Nglycosylation sites of human acid sphingomyelinase by site-directed mutagenesis. Eur. J. Biochem. 1997, 243, 511-517. [CrossRef]

21. Hurwitz, R.; Ferlinz, K.; Vielhaber, G.; Moczall, H.; Sandhoff, K. Processing of human acid sphingomyelinase in normal and I-cell fibroblasts. J. Biol. Chem. 1994, 269, 5440-5445. [CrossRef] 
22. Ferlinz, K.; Hurwitz, R.; Vielhaber, G.; Suzuki, K.; Sandhoff, K. Occurrence of two molecular forms of human acid sphingomyelinase. Biochem. J. 1994, 301, 855-862. [CrossRef]

23. Lefrancois, S.; Zeng, J.; Hassan, A.J.; Canuel, M.; Morales, C.R. The lysosomal trafficking of sphingolipid activator proteins (SAPs) is mediated by sortilin. EMBO J. 2003, 22, 6430-6437. [CrossRef]

24. Wähe, A.; Kasmapour, B.; Schmaderer, C.; Liebl, D.; Sandhoff, K.; Nykjaer, A.; Griffiths, G.; Gutierrez, M.G. Golgi-to-phagosome transport of acid sphingomyelinase and prosaposin is mediated by sortilin. J. Cell Sci. 2010, 123, 2502-2511. [CrossRef] [PubMed]

25. Ni, X.; Morales, C.R. The lysosomal trafficking of acid sphingomyelinase is mediated by sortilin and mannose 6-phosphate receptor. Traffic 2006, 7, 889-902. [CrossRef] [PubMed]

26. Romiti, E.; Vasta, V.; Meacci, E.; Farnararo, M.; Linke, T.; Ferlinz, K.; Sandhoff, K.; Bruni, P. Characterization of sphingomyelinase activity released by thrombin-stimulated platelets. Mol. Cell Biochem. 2000, 205, 75-81. [CrossRef]

27. Jenkins, R.W.; Idkowiak-Baldys, J.; Simbari, F.; Canals, D.; Roddy, P.; Riner, C.D.; Clarke, C.J.; Hannun, Y.A. A novel mechanism of lysosomal acid sphingomyelinase maturation: Requirement for carboxyl-terminal proteolytic processing. J. Biol. Chem. 2011, 286, 3777-3788. [CrossRef] [PubMed]

28. Hurwitz, R.; Ferlinz, K.; Sandhoff, K. The tricyclic antidepressant desipramine causes proteolytic degradation of lysosomal sphingomyelinase in human fibroblasts. Biol. Chem. Hoppe-Seyler 1994, 375, 447-450. [CrossRef]

29. Moles, A.; Tarrats, N.; Fernández-Checa, J.C.; Marí, M. Cathepsin B overexpression due to acid sphingomyelinase ablation promotes liver fibrosis in Niemann-Pick disease. J. Biol. Chem. 2012, 287, 1178-1188. [CrossRef] [PubMed]

30. Saftig, P.; Sandhoff, K. Cancer: Killing from the inside. Nature 2013, 502, 312-313. [CrossRef]

31. Gabandé-Rodríguez, E.; Boya, P.; Labrador, V.; Dotti, C.G.; Ledesma, M.D. High sphingomyelin levels induce lysosomal damage and autophagy dysfunction in Niemann Pick disease type A. Cell Death Differ. 2014, 21, 864-875. [CrossRef] [PubMed]

32. Schissel, S.L.; Keesler, G.A.; Schuchman, E.H.; Williams, K.J.; Tabas, I. The cellular trafficking and zinc dependence of secretory and lysosomal sphingomyelinase, two products of the acid sphingomyelinase gene. J. Biol. Chem. 1998, 273, 18250-18259. [CrossRef] [PubMed]

33. Xiong, Z.J.; Huang, J.; Poda, G.; Pomès, R.; Privé, G.G. Structure of human acid sphingomyelinase reveals the role of the saposin domain in activating substrate hydrolysis. J. Mol. Biol. 2016, 428, 3026-3042. [CrossRef] [PubMed]

34. Henseler, M.; Klein, A.; Glombitza, G.J.; Suziki, K.; Sandhoff, K. Expression of the three alternative forms of the sphingolipid activator protein precursor in baby hamster kidney cells and functional assays in a cell culture system. J. Biol. Chem. 1996, 271, 8416-8423. [CrossRef] [PubMed]

35. Burkhardt, J.K.; Hüttler, S.; Klein, A.; Möbius, W.; Habermann, A.; Griffiths, G.; Sandhoff, K. Accumulation of sphingolipids in SAP-precursor (prosaposin)-deficient fibroblasts occurs as intralysosomal membrane structures and can be completely reversed by treatment with human SAP-precursor. Eur. J. Cell Biol. 1997, 73, 10-18.

36. Ahn, V.E.; Faull, K.F.; Whitelegge, J.P.; Fluharty, A.L.; Privé, G.G. Crystal structure of saposin B reveals a dimeric shell for lipid binding. Proc. Natl. Acad. Sci. USA 2003, 100, 38-43. [CrossRef]

37. Popovic, K.; Holyoake, J.; Pomes, R.; Prive, G.G. Structure of saposin A lipoprotein discs. Proc. Natl. Acad. Sci. USA 2012, 109, 2908-2912. [CrossRef]

38. Gorelik, A.; Illes, K.; Heinz, L.X.; Superti-Furga, G.; Nagar, B. Crystal structure of mammalian acid sphingomyelinase. Nat. Commun. 2016, 7, 12196. [CrossRef] [PubMed]

39. Zhou, Y.-F.; Metcalf, M.C.; Garman, S.C.; Edmunds, T.; Qiu, H.; Wei, R.R. Human acid sphingomyelinase structures provide insight to molecular basis of Niemann-Pick disease. Nat. Commun. 2016, 7, 13082. [CrossRef]

40. Ota, S.; Noguchi, A.; Kondo, D.; Nakajima, Y.; Ito, T.; Arai, H.; Takahashi, T. An early-onset neuronopathic form of acid sphingomyelinase deficiency: A SMPD1 p.C133Y mutation in the saposin domain of acid sphingomyelinase. Tohoku J. Exp. Med. 2020, 250, 5-11. [CrossRef] [PubMed]

41. Ferlinz, K.; Linke, T.; Bartelsen, O.; Weiler, M.; Sandhoff, K. Stimulation of lysosomal sphingomyelin degradation by sphingolipid activator proteins. Chem. Phys. Lipids 1999, 102, 35-43. [CrossRef]

42. Linke, T.; Wilkening, G.; Lansmann, S.; Moczall, H.; Bartelsen, O.; Weisgerber, J.; Sandhoff, K. Stimulation of acid sphingomyelinase activity by lysosomal lipids and sphingolipid activator proteins. Biol. Chem. 2001, 382, 283-290. [CrossRef]

43. Abdul-Hammed, M.; Breiden, B.; Schwarzmann, G.; Sandhoff, K. Lipids regulate the hydrolysis of membrane bound glucosylceramide by lysosomal $\beta$-glucocerebrosidase. J. Lipid Res. 2017, 58, 563-577. [CrossRef] [PubMed]

44. Linke, T.; Wilkening, G.; Sadeghlar, F.; Mozcall, H.; Bernardo, K.; Schuchman, E.; Sandhoff, K. Interfacial regulation of acid ceramidase activity. Stimulation of ceramide degradation by lysosomal lipids and sphingolipid activator proteins. J. Biol. Chem. 2001, 276, 5760-5768. [CrossRef] [PubMed]

45. Wilkening, G.; Linke, T.; Uhlhorn-Dierks, G.; Sandhoff, K. Degradation of membrane-bound ganglioside GM1. Stimulation by bis(monoacylglycero)phosphate and the activator proteins SAP-B and GM2-AP. J. Biol. Chem. 2000, 275, 35814-35819. [CrossRef] [PubMed]

46. Anheuser, S.; Breiden, B.; Sandhoff, K. Membrane lipids and their degradation compounds control GM2 catabolism at intralysosomal luminal vesicles. J. Lipid Res. 2019, 60, 1099-1111. [CrossRef]

47. Sandhoff, R.; Sandhoff, K. Emerging concepts of ganglioside metabolism. FEBS Lett. 2018, 592, 3835-3864. [CrossRef] [PubMed]

48. Oninla, V.O.; Breiden, B.; Babalola, J.O.; Sandhoff, K. Acid sphingomyelinase activity is regulated by membrane lipids and facilitates cholesterol transfer by NPC2. J. Lipid Res. 2014, 55, 2606-2619. [CrossRef] [PubMed] 
49. Breiden, B.; Sandhoff, K. Lysosomal glycosphingolipid storage diseases. Annu. Rev. Biochem. 2019, 88, 461-485. [CrossRef]

50. Anheuser, S.; Breiden, B.; Schwarzmann, G.; Sandhoff, K. Membrane lipids regulate ganglioside GM2 catabolism and GM2 activator protein activity. J. Lipid Res. 2015, 56, 1747-1761. [CrossRef]

51. Matzner, U.; Breiden, B.; Schwarzmann, G.; Yaghootfam, A.; Fluharty, A.L.; Hasilik, A.; Sandhoff, K.; Gieselmann, V. Saposin B-dependent reconstitution of arylsulfatase A activity in vitro and in cell culture models of Metachromatic Leukodystrophy. $J$. Biol. Chem. 2009, 284, 9372-9381. [CrossRef]

52. Breiden, B.; Sandhoff, K. Emerging mechanisms of drug-induced phospholipidosis. Biol. Chem. 2020, 401, 31-46. [CrossRef]

53. Breiden, B.; Sandhoff, K. Mechanism of secondary ganglioside and lipid accumulation in lysosomal disease. Int. J. Mol. Sci. 2020, 21, 2566. [CrossRef]

54. Shayman, J.A.; Tesmer, J.J.G. Lysosomal phospholipase A2. Biochim. Biophys. Acta 2019, 1864, 932-940. [CrossRef]

55. Freeman, S.J.; Shankaran, P.; Wolfe, L.S.; Callahan, J.W. Phosphatidylcholine and 4-methylumbelliferyl phosphorylcholine hydrolysis by purified placental sphingomyelinase. Can. J. Biochem. Cell Biol. 1985, 63, 272-277. [CrossRef] [PubMed]

56. Huterer, S.; Wherrett, J.R.; Poulos, A.; Callahan, J.W. Deficiency of phospholipase C acting on phosphatidylglycerol in NiemannPick disease. Neurology 1983, 33, 67-73. [CrossRef] [PubMed]

57. Matsuzawa, Y.; Hostetler, K.Y. Properties of phospholipase C isolated from rat liver lysosomes. J. Biol. Chem. 1980, 255, 646-652. [CrossRef]

58. Hostetler, K.Y.; Hall, L.B. Phospholipase C activity of rat tissues. Biochem. Biophys. Res. Commun. 1980, 96, 388-393. [CrossRef]

59. Hostetler, K.Y.; Hall, L.B. Inhibition of kidney lysosomal phospholipases A and C by aminoglycoside antibiotics: Possible mechanism of aminoglycoside toxicity. Proc. Natl. Acad. Sci. USA. 1982, 79, 1663-1667. [CrossRef]

60. Eisen, D.; Bartolf, M.; Franson, R.C. Inhibition of lysosomal phospholipases C and A in rabbit alveolar macrophages, polymorphonuclear leukocytes and rat liver by sodium bisulfite. Biochim. Biophys. Acta 1984, 793, 10-17. [CrossRef]

61. Beaudet, A.L.; Hampton, M.S.; Patel, K.; Sparrow, J.T. Acidic phospholipases in cultured human fibroblasts: Deficiency of phospholipase C in Niemann-Pick disease. Clin. Chim. Acta 1980, 108, 403-414. [CrossRef]

62. Lansmann, S.; Bartelsen, O.; Sandhoff, K. Purification and characterization of recombinant human acid sphingomyelinase expressed in insect Sf21 cells. Methods Enzymol. 2000, 311, 149-156. [CrossRef]

63. Grabner, G.F.; Fawzy, N.; Schreiber, R.; Pusch, L.M.; Bulfon, D.; Koefeler, H.; Eichmann, T.O.; Lass, A.; Schweiger, M.; Marsche, G.; et al. Metabolic regulation of the lysosomal cofactor bis(monoacylglycero)phosphate in mice. J. Lipid Res. 2020, 61, 995-1003. [CrossRef]

64. Matsuzawa, Y.; Hostetler, K.Y. Degradation of bis(monoacylglycero)phosphate by an acid phosphodiesterase in rat liver lysosomes. J. Biol. Chem. 1979, 254, 5997-6001. [CrossRef]

65. Breilyn, M.S.; Zhang, W.; Yu, C.; Wasserstein, M.P. Plasma lyso-sphingomyelin levels are positively associated with clinical severity in acid sphingomyelinase deficiency. Mol. Genet. Metab. Rep. 2021, 28, 100780. [CrossRef]

66. Thurberg, B.L. Autopsy pathology of infantile neurovisceral ASMD (Niemann-Pick Disease type A): Clinicopathologic correlations of a case report. Mol. Genet. Metab. Rep. 2020, 24, 100626. [CrossRef] [PubMed]

67. Gulbins, E.; Kolesnick, R. Raft ceramide in molecular medicine. Oncogene 2003, 22, 7070-7077. [CrossRef] [PubMed]

68. Hagemann, N.; Mohamud Yusuf, A.; Martiny, C.; Zhang, X.; Kleinschnitz, C.; Gunzer, M.; Kolesnick, R.; Gulbins, E.; Hermann, D.M. Homozygous Smpd1 deficiency aggravates brain ischemia/reperfusion injury by mechanisms involving polymorphonuclear neutrophils, whereas heterozygous Smpd1 deficiency protects against mild focal cerebral ischemia. Basic Res. Cardiol. 2020, 115, 64. [CrossRef]

69. Paris, F.; Fuks, Z.; Kang, A.; Capodieci, P.; Juan, G.; Ehleiter, D.; Haimovitz-Friedman, A.; Cordon-Cardo, C.; Kolesnick, R. Endothelial apoptosis as the primary lesion initiating intestinal radiation damage in mice. Science 2001, 293, 293-297. [CrossRef] [PubMed]

70. Garcia-Barros, M.; Paris, F.; Cordon-Cardo, C.; Lyden, D.; Rafii, S.; Haimovitz-Friedman, A.; Fuks, Z.; Kolesnick, R. Tumor response to radiotherapy regulated by endothelial cell apoptosis. Science 2003, 300, 1155-1159. [CrossRef]

71. Ordoñez, M.; Presa, N.; Dominguez-Herrera, A.; Trueba, M.; Gomez-Muñoz, A. Regulation of adipogenesis by ceramide 1-phosphate. Exp. Cell Res. 2018, 372, 150-157. [CrossRef]

72. Mena, H.A.; Zubiry, P.R.; Dizier, B.; Mignon, V.; Parborell, F.; Schattner, M.; Boisson-Vidal, C.; Negrotto, S. Ceramide 1-phosphate protects endothelial colony-forming cells from apoptosis and increases vasculogenesis in vitro and in vivo. Arterioscler. Thromb. Vasc. Biol. 2019, 39, e219-e232. [CrossRef]

73. Gomez-Muñoz, A.; Duffy, P.A.; Martin, A.; O’Brien, L.; Byun, H.S.; Bittman, R.; Brindley, D.N. Short-chain ceramide-1-phosphates are novel stimulators of DNA synthesis and cell division: Antagonism by cell-permeable ceramides. Mol. Pharmacol. 1995, 47, 833-839.

74. Gatt, S.; Herzl, A.; Barenholz, Y. Hydrolysis of sphingomyelin liposomes by sphingomyelinase. FEBS Lett. 1973, 30, 281-285. [CrossRef]

75. Kölzer, M.; Arenz, C.; Ferlinz, K.; Werth, N.; Schulze, H.; Klingenstein, R.; Sandhoff, K. Phosphatidylinositol-3,5-Bisphosphate is a potent and selective inhibitor of acid sphingomyelinase. Biol. Chem. 2003, 384, 1293-1298. [CrossRef] [PubMed]

76. Testai, F.D.; Landek, M.A.; Goswami, R.; Ahmed, M.; Dawson, G. Acid sphingomyelinase and inhibition by phosphate ion: Role of inhibition by phosphatidyl-myo-inositol 3,4,5-triphosphate in oligodendrocyte cell signaling. J. Neurochem. 2004, 89, 636-644. [CrossRef] [PubMed] 
77. Gómez-Muñoz, A.; Kong, J.; Salh, B.; Steinbrecher, U.P. Sphingosine-1-phosphate inhibits acid sphingomyelinase and blocks apoptosis in macrophages. FEBS Lett. 2003, 539, 56-60. [CrossRef]

78. De Duve, C.; Wattiaux, R. Functions of lysosomes. Annu. Rev. Physiol. 1966, 28, 435-492. [CrossRef] [PubMed]

79. Savini, M.; Zhao, Q.; Wang, M.C. Lysosomes: Signaling hubs for metabolic sensing and longevity. Trends Cell Biol. 2019, 29, 876-887. [CrossRef] [PubMed]

80. Yim, W.W.-Y.; Mizushima, N. Lysosome biology in autophagy. Cell Discov. 2020, 6, 1-12. [CrossRef]

81. Kolter, T.; Sandhoff, K. Principles of lysosomal membrane digestion: Stimulation of sphingolipid degradation by sphingolipid activator proteins and anionic lysosomal lipids. Annu Rev. Cell Dev. Biol. 2005, 21, 81-103. [CrossRef] [PubMed]

82. Gruenberg, J. Life in the lumen: The multivesicular endosome. Traffic 2020, 21, 76-93. [CrossRef]

83. Finkbeiner, S. The autophagy lysosomal pathway and neurodegeneration. Cold Spring Harb. Perspect. Biol. 2020, 12, a033993. [CrossRef]

84. Herb, M.; Gluschko, A.; Schramm, M. LC3-associated phagocytosis-The highway to hell for phagocytosed microbes. In Seminars in Cell \& Developmental Biology; Academic Press: Cambridge, MA, USA, 2020; Volume 101, pp. 68-76. [CrossRef]

85. Ferguson, S.M. Neuronal lysosomes. Neurosci. Lett. 2019, 697, 1-9. [CrossRef]

86. Parenti, G.; Andria, G.; Ballabio, A. Lysosomal storage diseases: From pathophysiology to therapy. Annu. Rev. Med. 2015, 66, 471-486. [CrossRef]

87. Möbius, W.; Herzog, V.; Sandhoff, K.; Schwarzmann, G. Intracellular distribution of a biotin-labeled ganglioside, GM1, by immunoelectron microscopy after endocytosis in fibroblasts. J. Histochem. Cytochem. 1999, 47, 1005-1014. [CrossRef]

88. Wollert, T.; Hurley, J.H. Molecular mechanism of multivesicular body biogenesis by ESCRT complexes. Nature 2010, 464, 864-869. [CrossRef]

89. Eskelinen, E.-L.; Tanaka, Y.; Saftig, P. At the acidic edge: Emerging functions for lysosomal membrane proteins. Trends Cell Biol. 2003, 13, 137-145. [CrossRef]

90. Gallala, H.; Sandhoff, K. Biological function of the cellular lipid BMP-BMP as a key activator for cholesterol sorting and membrane digestion. Neurochem. Res. 2011, 36, 1594-1600. [CrossRef]

91. Remmel, N.; Locatelli-Hoops, S.; Breiden, B.; Schwarzmann, G.; Sandhoff, K. Saposin B mobilizes lipids from cholesterol-poor and bis(monoacylglycero)phosphate-rich membranes at acidic $\mathrm{pH}$. Unglycosylated patient variant saposin B lacks lipid-extraction capacity. FEBS J. 2007, 274, 3405-3420. [CrossRef]

92. Locatelli-Hoops, S.; Remmel, N.; Klingenstein, R.; Breiden, B.; Rossocha, M.; Schoeniger, M.; Koenigs, C.; Saenger, W.; Sandhoff, K. Saposin A mobilizes lipids from low cholesterol and high bis(monoacylglycerol)phosphate-containing membranes: Patient variant Saposin A lacks lipid extraction capacity. J. Biol. Chem. 2006, 281, 32451-32460. [CrossRef]

93. Anheuser, S.; Breiden, B.; Sandhoff, K. Ganglioside GM2 catabolism is inhibited by storage compounds of mucopolysaccharidoses and by cationic amphiphilic drugs. Mol. Genet. Metab. 2019, 128, 75-83. [CrossRef]

94. Kamoshita, S.; Aron, A.M.; Suzuki, K.; Suzuki, K. Infantile Niemann-Pick disease. A chemical study with isolation and characterization of membranous cytoplasmic bodies and myelin. Am. J. Dis. Child. 1969, 117, 379-394. [CrossRef]

95. Jatzkewitz, H.; Pilz, H.; Sandhoff, K. Quantitative Bestimmungen von Gangliosiden und ihren Neuraminsäurefreien Derivaten bei infantilen, juvenilen und adulten Formen der amaurotischen Idiotie und einer spätinfantilen biochemischen Sonderform. J. Neurochem. 1965, 12, 135-144. [CrossRef] [PubMed]

96. Abdul-Hammed, M.; Breiden, B.; Adebayo, M.A.; Babalola, J.O.; Schwarzmann, G.; Sandhoff, K. Role of endosomal membrane lipids and NPC2 in cholesterol transfer and membrane fusion. J. Lipid Res. 2010, 51, 1747-1760. [CrossRef] [PubMed]

97. Ruiz-Argüello, M.B.; Basáñez, G.; Goñi, F.M.; Alonso, A. Different effects of enzyme-generated ceramides and diacylglycerols in phospholipid membrane fusion and leakage. J. Biol. Chem. 1996, 271, 26616-26621. [CrossRef]

98. Morimoto, S.; Martin, B.M.; Kishimoto, Y.; O’Brien, J.S. Saposin D: A sphingomyelinase activator. Biochem. Biophys. Res. Commun. 1988, 156, 403-410. [CrossRef]

99. Graf, C.G.F.; Schulz, C.; Schmälzlein, M.; Heinlein, C.; Mönnich, M.; Perkams, L.; Püttner, M.; Boos, I.; Hessefort, M.; Lombana Sanchez, J.N.; et al. Synthetic glycoforms reveal carbohydrate-dependent bioactivity of human saposin D. Angew. Chem. Int. Ed. 2017, 56, 5252-5257. [CrossRef]

100. Schwarzmann, G.; Breiden, B.; Sandhoff, K. Membrane-spanning lipids for an uncompromised monitoring of membrane fusion and intermembrane lipid transfer. J. Lipid Res. 2015, 56, 1861-1879. [CrossRef]

101. Vaccaro, A.M.; Ciaffoni, F.; Tatti, M.; Salvioli, R.; Barca, A.; Tognozzi, D.; Scerch, C. pH-dependent conformational properties of saposins and their interactions with phospholipid membranes. J. Biol. Chem. 1995, 270, 30576-30580. [CrossRef]

102. Vaccaro, A.M.; Salvioli, R.; Tatti, M.; Ciaffoni, F. Saposins and their interaction with lipids. Neurochem. Res. 1999, $24,307-314$. [CrossRef]

103. Vaccaro, A.M.; Tatti, M.; Ciaffoni, F.; Salvioli, R.; Serafino, A.; Barca, A. Saposin-C induces pH-dependent destabilization and fusion of phosphatidylserine-containing vesicles. FEBS Lett. 1994, 349, 181-186. [CrossRef]

104. Qi, X.; Chu, Z. Fusogenic domain and lysines in saposin C. Arch. Biochem. Biophys. 2004, 424, 210-218. [CrossRef]

105. Kölzer, M.; Ferlinz, K.; Bartelsen, O.; Hoops, S.L.; Lang, F.; Sandhoff, K. Functional characterization of the postulated intramolecular sphingolipid activator protein domain of human acid sphingomyelinase. Biol. Chem. 2004, 385, 1193-1195. [CrossRef]

106. Kobayashi, T.; Beuchat, M.H.; Chevallier, J.; Makino, A.; Mayran, N.; Escola, J.M.; Lebrand, C.; Cosson, P.; Gruenberg, J. Separation and characterization of late endosomal membrane domains. J. Biol. Chem. 2002, 277, 32157-32164. [CrossRef] [PubMed] 
107. Möbius, W.; van Donselaar, E.; Ohno-Iwashita, Y.; Shimada, Y.; Heijnen, H.F.; Slot, J.W.; Geuze, H.J. Recycling compartments and the internal vesicles of multivesicular bodies harbor most of the cholesterol found in the endocytic pathway. Traffic 2003, 4, 222-231. [CrossRef]

108. Kölzer, M.; Werth, N.; Sandhoff, K. Interactions of acid sphingomyelinase and lipid bilayers in the presence of the tricyclic antidepressant desipramine. FEBS Lett. 2004, 559, 96-98. [CrossRef]

109. Cockburn, C.L.; Green, R.S.; Damle, S.R.; Martin, R.K.; Ghahrai, N.N.; Colonne, P.M.; Fullerton, M.S.; Conrad, D.H.; Chalfant, C.E.; Voth, D.E.; et al. Functional inhibition of acid sphingomyelinase disrupts infection by intracellular bacterial pathogens. Life Sci. Alliance 2019, 2. [CrossRef] [PubMed]

110. Elojeimy, S.; Holman, D.H.; Liu, X.; El-Zawahry, A.; Villani, M.; Cheng, J.C.; Mahdy, A.; Zeidan, Y.; Bielwaska, A.; Hannun, Y.A.; et al. New insights on the use of desipramine as an inhibitor for acid ceramidase. FEBS Lett. 2006, 580, 4751-4756. [CrossRef] [PubMed]

111. Ellegaard, A.M.; Bach, P.; Jäättelä, M. Targeting cancer lysosomes with good old cationic amphiphilic drugs. Rev. Physiol. Biochem. Pharmacol. 2021. [CrossRef]

112. Berger, A.; Rosenthal, D.; Spiegel, S. Sphingosylphosphocholine, a signaling molecule which accumulates in Niemann-Pick disease type A, stimulates DNA-binding activity of the transcription activator protein AP-1. Proc. Natl. Acad. Sci. USA 1995, 92, 5885-5889. [CrossRef]

113. Rouser, G.; Kritchevsky, G.; Knudson, A.G., Jr.; Simon, G. Accumulation of a glycerolphospholipid in classical niemann-pick disease. Lipids 1968, 3, 287-290. [CrossRef] [PubMed]

114. Vanier, M.T. Biochemical studies in Niemann-Pick disease I. Major sphingolipids of liver and spleen. Biochim. Biophys. Acta (BBA)-Lipids Lipid Metab. 1983, 750, 178-184. [CrossRef]

115. Newcomb, B.; Rhein, C.; Mileva, I.; Ahmad, R.; Clarke, C.J.; Snider, J.; Obeid, L.M.; Hannun, Y.A. Identification of an acid sphingomyelinase ceramide kinase pathway in the regulation of the chemokine CCL5. J. Lipid Res. 2018, 59, 1219-1229. [CrossRef] [PubMed]

116. Presa, N.; Gomez-Larrauri, A.; Dominguez-Herrera, A.; Trueba, M.; Gomez-Muñoz, A. Novel signaling aspects of ceramide 1-phosphate. Biochim. Biophys. Acta (BBA)-Mol. Cell Biol. Lipids 2020, 1865, 158630. [CrossRef] [PubMed]

117. Dadsena, S.; Bockelmann, S.; Mina, J.G.M.; Hassan, D.G.; Korneev, S.; Razzera, G.; Jahn, H.; Niekamp, P.; Müller, D.; Schneider, M.; et al. Ceramides bind VDAC2 to trigger mitochondrial apoptosis. Nat. Commun. 2019, 10, 1832. [CrossRef]

118. Leonetti, D.; Estéphan, H.; Ripoche, N.; Dubois, N.; Aguesse, A.; Gouard, S.; Brossard, L.; Chiavassa, S.; Corre, I.; Pecqueur, C.; et al. Secretion of acid sphingomyelinase and ceramide by endothelial cells contributes to radiation-induced intestinal toxicity. Cancer Res. 2020, 80, 2651-2662. [CrossRef] [PubMed]

119. Ketteler, J.; Wittka, A.; Leonetti, D.; Roy, V.V.; Estephan, H.; Maier, P.; Reis, H.; Herskind, C.; Jendrossek, V.; Paris, F.; et al. Caveolin-1 regulates the ASMase/ceramide-mediated radiation response of endothelial cells in the context of tumor-stroma interactions. Cell Death Dis. 2020, 11, 228. [CrossRef]

120. Henry, B.; Ziobro, R.; Becker, K.; Kolesnick, R.; Gulbins, E. Acid Sphingomyelinase. In Sphingolipids: Basic Science and Drug Development, 215th ed.; Gulbins, E., Petrache, I., Eds.; Springer: Vienna, Austria, 2013; pp. 77-88.

121. Rana, S.; Espinosa-Diez, C.; Ruhl, R.; Chatterjee, N.; Hudson, C.; Fraile-Bethencourt, E.; Agarwal, A.; Khou, S.; Thomas, C.R., Jr.; Anand, S. Differential regulation of microRNA-15a by radiation affects angiogenesis and tumor growth via modulation of acid sphingomyelinase. Sci. Rep. 2020, 10, 5581. [CrossRef]

122. Heneweer, C.; Penate Medina, T.; Tower, R.; Kalthoff, H.; Kolesnick, R.; Larson, S.; Penate Medina, O. Acid-sphingomyelinase triggered fluorescently labeled sphingomyelin containing liposomes in tumor diagnosis after radiation-induced stress. Int. J. Mol. Sci. 2021, 22, 3864. [CrossRef]

123. Kolesnick, R.; Fuks, Z. Radiation and ceramide-induced apoptosis. Oncogene 2003, 22, 5897-5906. [CrossRef]

124. Peña, L.A.; Fuks, Z.; Kolesnick, R.N. Radiation-induced apoptosis of endothelial cells in the murine central nervous system: Protection by fibroblast growth factor and sphingomyelinase deficiency. Cancer Res. 2000, 60, 321-327. [PubMed]

125. Contreras, F.X.; Villar, A.V.; Alonso, A.; Kolesnick, R.N.; Goñi, F.M. Sphingomyelinase activity causes transbilayer lipid translocation in model and cell membranes. J. Biol. Chem. 2003, 278, 37169-37174. [CrossRef]

126. Tam, C.; Idone, V.; Devlin, C.; Fernandes, M.C.; Flannery, A.; He, X.; Schuchman, E.; Tabas, I.; Andrews, N.W. Exocytosis of acid sphingomyelinase by wounded cells promotes endocytosis and plasma membrane repair. J. Cell Biol. 2010, 189, 1027-1038. [CrossRef]

127. Reddy, A.; Caler, E.V.; Andrews, N.W. Plasma membrane repair is mediated by Ca(2+)-regulated exocytosis of lysosomes. Cell 2001, 106, 157-169. [CrossRef]

128. Rhein, C.; Zoicas, I.; Marx, L.M.; Zeitler, S.; Hepp, T.; von Zimmermann, C.; Mühle, C.; Richter-Schmidinger, T.; Lenz, B.; Erim, Y.; et al. mRNA expression of SMPD1 encoding acid sphingomyelinase decreases upon antidepressant treatment. Int. J. Mol. Sci. 2021, 22, 5700. [CrossRef]

129. Zhang, L.; Dai, J.; Zeng, Z.; Jia, Y. Nitric oxide induces HepG2 cell death via extracellular signal-regulated protein kinase activation by regulating acid sphingomyelinase. Mol. Biol. Rep. 2020, 47, 8353-8359. [CrossRef] [PubMed]

130. Vadlamudi, Y.; Muthu, K.; Kumar, M.S. Structural exploration of acid sphingomyelinase at different physiological pH through molecular dynamics and docking studies. RSC Adv. 2016, 6, 74859-74873. [CrossRef] 
131. O'Sullivan, M.J.; Lindsay, A.J. The endosomal recycling pathway-at the crossroads of the cell. Int. J. Mol. Sci. 2020, $21,6074$. [CrossRef] [PubMed]

132. Chung, H.Y.; Claus, R.A. Keep your friends close, but your enemies closer: Role of acid sphingomyelinase during infection and host response. Front. Med. 2020, 7, 616500. [CrossRef]

133. Schissel, S.L.; Jiang, X.; Tweedie-Hardman, J.; Jeong, T.; Camejo, E.H.; Najib, J.; Rapp, J.H.; Williams, K.J.; Tabas, I. Secretory sphingomyelinase, a product of the acid sphingomyelinase gene, can hydrolyze atherogenic lipoproteins at neutral $\mathrm{pH}$. Implications for atherosclerotic lesion development. J. Biol. Chem. 1998, 273, 2738-2746. [CrossRef]

134. Mizrachi, A.; Ben-Aharon, I.; Li, H.; Bar-Joseph, H.; Bodden, C.; Hikri, E.; Popovtzer, A.; Shalgi, R.; Haimovitz-Friedman, A. Chemotherapy-induced acute vascular injury involves intracellular generation of ROS via activation of the acid sphingomyelinase pathway. Cell. Signal. 2021, 82, 109969. [CrossRef]

135. Thayyullathil, F.; Cheratta, A.R.; Alakkal, A.; Subburayan, K.; Pallichankandy, S.; Hannun, Y.A.; Galadari, S. Acid sphingomyelinase-dependent autophagic degradation of GPX4 is critical for the execution of ferroptosis. Cell Death Dis. 2021, 12, 26. [CrossRef]

136. Luong, T.T.D.; Tuffaha, R.; Schuchardt, M.; Moser, B.; Schelski, N.; Boehme, B.; Gollmann-Tepekoylu, C.; Schramm, C.; Holfeld, J.; Pieske, B.; et al. Acid sphingomyelinase promotes SGK1-dependent vascular calcification. Clin. Sci. 2021, 135, 515-534. [CrossRef]

137. Pinkert, T.; Furkert, D.; Korte, T.; Herrmann, A.; Arenz, C. Amplification of a FRET Probe by lipid-water partition for the detection of acid sphingomyelinase in live cells. Angew Chem. Int. Ed. 2017, 56, 2790-2794. [CrossRef]

138. Kappe, C.; Mohamed, Z.H.; Naser, E.; Carpinteiro, A.; Arenz, C. A novel visible range FRET probe for monitoring acid sphingomyelinase activity in living cells. Chemistry 2020, 26, 5780-5783. [CrossRef]

139. Mohamed, Z.H.; Rhein, C.; Schmid, B.; Tripal, P.; Kornhuber, J.; Arenz, C. Synthesis and characterization of a new two photon excitable acid sphingomyelinase FRET probe. Bioorganic Med. Chem. 2021, 44, 116303. [CrossRef] [PubMed]

140. Prause, K.; Naseri, G.; Schumacher, F.; Kappe, C.; Kleuser, B.; Arenz, C. A photocaged inhibitor of acid sphingomyelinase. Chem. Commun. 2020, 56, 14885-14888. [CrossRef] [PubMed]

141. Holme, M.N.; Rana, S.; Barriga, H.M.G.; Kauscher, U.; Brooks, N.J.; Stevens, M.M. A robust liposomal platform for direct colorimetric detection of sphingomyelinase enzyme and inhibitors. ACS Nano 2018, 12, 8197-8207. [CrossRef]

142. Arenz, C. Small molecule inhibitors of acid sphingomyelinase. Cell Physiol. Biochem. 2010, 26, 1-8. [CrossRef] [PubMed]

143. Kornhuber, J.; Tripal, P.; Reichel, M.; Terfloth, L.; Bleich, S.; Wiltfang, J.; Gulbins, E. Identification of new functional inhibitors of acid sphingomyelinase using a structure-property-activity relation model. J. Med. Chem. 2007, 51, 219-237. [CrossRef]

144. Kornhuber, J.; Muehlbacher, M.; Trapp, S.; Pechmann, S.; Friedl, A.; Reichel, M.; Muhle, C.; Terfloth, L.; Groemer, T.W.; Spitzer, G.M.; et al. Identification of novel functional inhibitors of acid sphingomyelinase. PLoS ONE 2011, 6, e23852. [CrossRef]

145. Yang, K.; Nong, K.; Gu, Q.; Dong, J.; Wang, J. Discovery of N-hydroxy-3-alkoxybenzamides as direct acid sphingomyelinase inhibitors using a ligand-based pharmacophore model. Eur. J. Med. Chem. 2018, 151, 389-400. [CrossRef] [PubMed]

146. Yang, K.; Yu, J.; Nong, K.; Wang, Y.; Niu, A.; Chen, W.; Dong, J.; Wang, J. Discovery of potent, selective, and direct acid sphingomyelinase inhibitors with antidepressant activity. J. Med. Chem. 2020, 63, 961-974. [CrossRef] [PubMed]

147. Garrido, C.M.; Henkels, K.M.; Rehl, K.M.; Liang, H.; Zhou, Y.; Gutterman, J.U.; Cho, K.J. Avicin G is a potent sphingomyelinase inhibitor and blocks oncogenic K- and H-Ras signaling. Sci. Rep. 2020, 10, 9120. [CrossRef] [PubMed]

148. Naser, E.; Kadow, S.; Schumacher, F.; Mohamed, Z.H.; Kappe, C.; Hessler, G.; Pollmeier, B.; Kleuser, B.; Arenz, C.; Becker, K.A.; et al. Characterization of the small molecule ARC39, a direct and specific inhibitor of acid sphingomyelinase in vitro. J. Lipid Res. 2020, 61, 896-910. [CrossRef]

149. Böll, S.; Ziemann, S.; Ohl, K.; Klemm, P.; Rieg, A.D.; Gulbins, E.; Becker, K.A.; Kamler, M.; Wagner, N.; Uhlig, S.; et al. Acid sphingomyelinase regulates $\mathrm{T}(\mathrm{H}) 2$ cytokine release and bronchial asthma. Allergy 2020, 75, 603-615. [CrossRef]

150. Justice, M.J.; Bronova, I.; Schweitzer, K.S.; Poirier, C.; Blum, J.S.; Berdyshev, E.V.; Petrache, I. Inhibition of acid sphingomyelinase disrupts LYNUS signaling and triggers autophagy. J. Lipid Res. 2018, 59, 596-606. [CrossRef]

151. Gulbins, A.; Schumacher, F.; Becker, K.A.; Wilker, B.; Soddemann, M.; Boldrin, F.; Müller, C.P.; Edwards, M.J.; Goodman, M.; Caldwell, C.C.; et al. Antidepressants act by inducing autophagy controlled by sphingomyelin-ceramide. Mol. Psychiatry 2018, 23, 2324-2346. [CrossRef]

152. Li, X.; Jin, S.-J.; Su, J.; Li, X.-X.; Xu, M. Acid sphingomyelinase down-regulation alleviates vascular endothelial insulin resistance in diabetic rats. Basic Clin. Pharmacol. Toxicol. 2018, 123, 645-659. [CrossRef]

153. Jiang, M.; Huang, S.; Duan, W.; Liu, Q.; Lei, M. Inhibition of acid sphingomyelinase activity ameliorates endothelial dysfunction in $\mathrm{db} / \mathrm{db}$ mice. Biosci. Rep. 2019, 39. [CrossRef] [PubMed]

154. Lu, Z.; Li, Y.; Syn, W.K.; Wang, Z.; Lopes-Virella, M.F.; Lyons, T.J.; Huang, Y. Amitriptyline inhibits nonalcoholic steatohepatitis and atherosclerosis induced by high-fat diet and LPS through modulation of sphingolipid metabolism. Am. J. Physiol. Endocrinol. Metab. 2020, 318, E131-E144. [CrossRef]

155. Novgorodov, S.A.; Voltin, J.R.; Gooz, M.A.; Li, L.; Lemasters, J.J.; Gudz, T.I. Acid sphingomyelinase promotes mitochondrial dysfunction due to glutamate-induced regulated necrosis. J. Lipid Res. 2018, 59, 312-329. [CrossRef] [PubMed]

156. Lee, J.K.; Jin, H.K.; Park, M.H.; Kim, B.R.; Lee, P.H.; Nakauchi, H.; Carter, J.E.; He, X.; Schuchman, E.H.; Bae, J.S. Acid sphingomyelinase modulates the autophagic process by controlling lysosomal biogenesis in Alzheimer's disease. J. Exp. Med. 2014, 211, 1551-1570. [CrossRef] 
157. Faict, S.; Oudaert, I.; D’Auria, L.; Dehairs, J.; Maes, K.; Vlummens, P.; De Veirman, K.; De Bruyne, E.; Fostier, K.; Vande Broek, I.; et al. The transfer of sphingomyelinase contributes to drug resistance in multiple myeloma. Cancers 2019, 11, 1823. [CrossRef] [PubMed]

158. Pellkofer, R.; Sandhoff, K. Halothane increases membrane fluidity and stimulates sphingomyelin degradation by membranebound neutral sphingomyelinase of synaptosomal plasma membranes from calf brain already at clinical concentrations. $J$. Neurochem. 1980, 34, 988-992. [CrossRef] [PubMed]

159. Sandhoff, K.; Pallmann, B. Membrane-bound neuraminidase from calf brain: Regulation of oligosialoganglioside degradation by membrane fluidity and membrane components. Proc. Natl. Acad. Sci. USA 1978, 75, 122-126. [CrossRef] [PubMed]

160. Dinoff, A.; Herrmann, N.; Lanctôt, K.L. Ceramides and depression: A systematic review. J. Affect. Disord 2017, 213, 35-43. [CrossRef]

161. Santarelli, L.; Saxe, M.; Gross, C.; Surget, A.; Battaglia, F.; Dulawa, S.; Weisstaub, N.; Lee, J.; Duman, R.; Arancio, O.; et al. Requirement of hippocampal neurogenesis for the behavioral effects of antidepressants. Science 2003, 301, 805-809. [CrossRef] [PubMed]

162. Gulbins, E.; Palmada, M.; Reichel, M.; Lüth, A.; Böhmer, C.; Amato, D.; Müller, C.P.; Tischbirek, C.H.; Groemer, T.W.; Tabatabai, G.; et al. Acid sphingomyelinase-ceramide system mediates effects of antidepressant drugs. Nat. Med. 2013, 19, 934-938. [CrossRef]

163. Niziolek, G.M.; Hoehn, R.S.; Seitz, A.P.; Jernigan, P.L.; Makley, A.T.; Gulbins, E.; Edwards, M.J.; Goodman, M.D. The role of acid sphingomyelinase inhibition in repetitive mild traumatic brain injury. J. Surg. Res. 2020, 259, 296-304. [CrossRef]

164. Jaddoa, E.; Masania, J.; Masiero, E.; Sgamma, T.; Arroo, R.; Sillence, D.; Zetterström, T. Effect of antidepressant drugs on the brain sphingolipid system. J. Psychopharmacol. 2020, 34, 716-725. [CrossRef]

165. Zoicas, I.; Schumacher, F.; Kleuser, B.; Reichel, M.; Gulbins, E.; Fejtova, A.; Kornhuber, J.; Rhein, C. The forebrain-specific overexpression of acid sphingomyelinase induces depressive-like symptoms in mice. Cells 2020, 9, 1244. [CrossRef]

166. Zoicas, I.; Mühle, C.; Schmidtner, A.K.; Gulbins, E.; Neumann, I.D.; Kornhuber, J. Anxiety and depression are related to higher activity of sphingolipid metabolizing enzymes in the rat brain. Cells 2020, 9, 1239. [CrossRef]

167. Huston, J.P.; Kornhuber, J.; Mühle, C.; Japtok, L.; Komorowski, M.; Mattern, C.; Reichel, M.; Gulbins, E.; Kleuser, B.; Topic, B.; et al. A sphingolipid mechanism for behavioral extinction. J. Neurochem. 2016, 137, 589-603. [CrossRef] [PubMed]

168. Park, M.H.; Jin, H.K.; Bae, J.-S. Potential therapeutic target for aging and age-related neurodegenerative diseases: The role of acid sphingomyelinase. Exp. Mol. Med. 2020, 52, 380-389. [CrossRef] [PubMed]

169. Jung, J.H.; Taniguchi, K.; Lee, H.M.; Lee, M.Y.; Bandu, R.; Komura, K.; Lee, K.Y.; Akao, Y.; Kim, K.P. Comparative lipidomics of 5-Fluorouracil-sensitive and -resistant colorectal cancer cells reveals altered sphingomyelin and ceramide controlled by acid sphingomyelinase (SMPD1). Sci. Rep. 2020, 10, 6124. [CrossRef] [PubMed]

170. Brady, R.O. Enzyme replacement for lysosomal diseases. Annu. Rev. Med. 2006, 57, 283-296. [CrossRef]

171. Diaz, G.A.; Jones, S.A.; Scarpa, M.; Mengel, K.E.; Giugliani, R.; Guffon, N.; Batsu, I.; Fraser, P.A.; Li, J.; Zhang, Q.; et al. One-year results of a clinical trial of olipudase alfa enzyme replacement therapy in pediatric patients with acid sphingomyelinase deficiency. Genet. Med. 2021, 1-8. [CrossRef]

172. Wasserstein, M.P.; Diaz, G.A.; Lachmann, R.H.; Jouvin, M.H.; Nandy, I.; Ji, A.J.; Puga, A.C. Olipudase alfa for treatment of acid sphingomyelinase deficiency (ASMD): Safety and efficacy in adults treated for 30 months. J. Inherit. Metab. Dis. 2018, 41, 829-838. [CrossRef]

173. Wasserstein, M.P.; Jones, S.A.; Soran, H.; Diaz, G.A.; Lippa, N.; Thurberg, B.L.; Culm-Merdek, K.; Shamiyeh, E.; Inguilizian, H.; Cox, G.F.; et al. Successful within-patient dose escalation of olipudase alfa in acid sphingomyelinase deficiency. Mol. Genet. Metab. 2015, 116, 88-97. [CrossRef]

174. Aldosari, M.H.; de Vries, R.P.; Rodriguez, L.R.; Hesen, N.A.; Beztsinna, N.; van Kuilenburg, A.B.P.; Hollak, C.E.M.; Schellekens, H.; Mastrobattista, E. Liposome-targeted recombinant human acid sphingomyelinase: Production, formulation, and in vitro evaluation. Eur. J. Pharm. Biopharm. 2019, 137, 185-195. [CrossRef]

175. Simonis, A.; Schubert-Unkmeir, A. The role of acid sphingomyelinase and modulation of sphingolipid metabolism in bacterial infection. Biol. Chem. 2018, 399, 1135-1146. [CrossRef]

176. Wu, Y.; Gulbins, E.; Grassmé, H. The function of sphingomyelinases in mycobacterial infections. Biol. Chem. 2018, 399, 1125-1133. [CrossRef] [PubMed]

177. Wu, Y.; Li, C.; Peng, H.; Swaidan, A.; Riehle, A.; Pollmeier, B.; Zhang, Y.; Gulbins, E.; Grassmé, H. Acid sphingomyelinase contributes to the control of mycobacterial infection via a signaling cascade leading from reactive oxygen species to cathepsin $\mathrm{D}$. Cells 2020, 9, 2406. [CrossRef]

178. Naimi, W.A.; Gumpf, J.J.; Cockburn, C.L.; Camus, S.; Chalfant, C.E.; Li, P.L.; Carlyon, J.A. Functional inhibition or genetic deletion of acid sphingomyelinase bacteriostatically inhibits Anaplasma phagocytophilum infection in vivo. Pathog. Dis. 2021, 79. [CrossRef] [PubMed]

179. Meiners, J.; Palmieri, V.; Klopfleisch, R.; Ebel, J.F.; Japtok, L.; Schumacher, F.; Yusuf, A.M.; Becker, K.A.; Zöller, J.; Hose, M.; et al. Intestinal acid sphingomyelinase protects from severe pathogen-driven colitis. Front. Immunol. 2019, 10, 1386. [CrossRef] [PubMed]

180. Guzman, G.; Niekamp, P.; Tafesse, F.G. The squeaky yeast gets greased: The roles of host lipids in the clearance of pathogenic fungi. J. Fungi 2020, 6, 19. [CrossRef] [PubMed] 
181. Li, C.; Guo, S.; Pang, W.; Zhao, Z. Crosstalk between acid sphingomyelinase and inflammasome signaling and their emerging roles in tissue injury and fibrosis. Front. Cell Dev. Biol. 2020, 7, 378. [CrossRef]

182. White, J.M.; Whittaker, G.R. Fusion of enveloped viruses in endosomes. Traffic 2016, 17, 593-614. [CrossRef]

183. Kühnl, A.; Musiol, A.; Heitzig, N.; Johnson, D.E.; Ehrhardt, C.; Grewal, T.; Gerke, V.; Ludwig, S.; Rescher, U. Late endosomal/lysosomal cholesterol accumulation is a host cell-protective mechanism inhibiting endosomal escape of influenza A virus. MBio 2018, 9. [CrossRef]

184. Schoer, J.K.; Gallegos, A.M.; McIntosh, A.L.; Starodub, O.; Kier, A.B.; Billheimer, J.T.; Schroeder, F. Lysosomal membrane cholesterol dynamics. Biochemistry 2000, 39, 7662-7677. [CrossRef]

185. Shoemaker, C.J.; Schornberg, K.L.; Delos, S.E.; Scully, C.; Pajouhesh, H.; Olinger, G.G.; Johansen, L.M.; White, J.M. Multiple cationic amphiphiles induce a Niemann-Pick C phenotype and inhibit Ebola virus entry and infection. PLoS ONE 2013, 8, e56265. [CrossRef]

186. Wang, J.; Pendurthi, U.R.; Yi, G.; Rao, L.V.M. SARS-CoV-2 infection induces the activation of tissue factor-mediated coagulation by activation of acid sphingomyelinase. Blood 2021. [CrossRef] [PubMed]

187. Carpinteiro, A.; Edwards, M.J.; Hoffmann, M.; Kochs, G.; Gripp, B.; Weigang, S.; Adams, C.; Carpinteiro, E.; Gulbins, A.; Keitsch, S.; et al. Pharmacological inhibition of acid sphingomyelinase prevents uptake of SARS-CoV-2 by epithelial cells. Cell Rep. Med. 2020, 1, 100142. [CrossRef] [PubMed]

188. Schloer, S.; Brunotte, L.; Goretzko, J.; Mecate-Zambrano, A.; Korthals, N.; Gerke, V.; Ludwig, S.; Rescher, U. Targeting the endolysosomal host-SARS-CoV-2 interface by clinically licensed functional inhibitors of acid sphingomyelinase (FIASMA) including the antidepressant fluoxetine. Emerg. Microbes Infect. 2020, 9, 2245-2255. [CrossRef] [PubMed]

189. Loas, G.; Le Corre, P. Update on functional inhibitors of acid sphingomyelinase (FIASMAs) in SARS-CoV-2 infection. Pharmaceuticals 2021, 14, 691. [CrossRef] [PubMed]

190. Miller, M.E.; Adhikary, S.; Kolokoltsov, A.A.; Davey, R.A. Ebolavirus requires acid sphingomyelinase activity and plasma membrane sphingomyelin for infection. J. Virol. 2012, 86, 7473-7483. [CrossRef]

191. Salata, C.; Calistri, A.; Parolin, C.; Baritussio, A.; Palù, G. Antiviral activity of cationic amphiphilic drugs. Expert Rev. Anti Infect. Ther. 2017, 15, 483-492. [CrossRef]

192. Hoertel, N.; Sánchez-Rico, M.; Vernet, R.; Beeker, N.; Jannot, A.S.; Neuraz, A.; Salamanca, E.; Paris, N.; Daniel, C.; Gramfort, A.; et al. Association between antidepressant use and reduced risk of intubation or death in hospitalized patients with COVID-19: Results from an observational study. Mol. Psychiatry 2021, 1-14. [CrossRef]

193. Hoertel, N.; Sánchez-Rico, M.; Gulbins, E.; Kornhuber, J.; Carpinteiro, A.; Lenze, E.J.; Reiersen, A.M.; Abellán, M.; De La Muela, P.; Vernet, R.; et al. Association between FIASMAs and reduced risk of intubation or death in individuals hospitalized for severe COVID-19: An observational multicenter study. Clin. Pharmacol. Ther. 2021. [CrossRef]

194. Luquain-Costaz, C.; Rabia, M.; Hullin-Matsuda, F.; Delton, I. Bis(monoacylglycero)phosphate, an important actor in the host endocytic machinery hijacked by SARS-CoV-2 and related viruses. Biochimie 2020. [CrossRef]

195. Martín-Acebes, M.A.; Gabandé-Rodríguez, E.; García-Cabrero, A.M.; Sánchez, M.P.; Ledesma, M.D.; Sobrino, F.; Saiz, J.C. Host sphingomyelin increases West Nile virus infection in vivo. J. Lipid Res. 2016, 57, 422-432. [CrossRef] [PubMed]

196. Edwards, M.J.; Becker, K.A.; Gripp, B.; Hoffmann, M.; Keitsch, S.; Wilker, B.; Soddemann, M.; Gulbins, A.; Carpinteiro, E.; Patel, S.H.; et al. Sphingosine prevents binding of SARS-CoV-2 spike to its cellular receptor ACE2. J. Biol. Chem. 2020, 295, 15174-15182. [CrossRef] [PubMed]

197. Walkley, S.U.; Vanier, M.T. Secondary lipid accumulation in lysosomal disease. Biochim. Biophys. Acta (BBA)-Mol. Cell Res. 2009, 1793, 726-736. [CrossRef] [PubMed] 